\title{
Familial classification of the Boraginales
}

\author{
Boraginales Working Group \\ Federico Luebert, ${ }^{1,2}$ Lorenzo Cecchi, ${ }^{3}$ Michael W. Frohlich, ${ }^{4}$ Marc Gottschling, ${ }^{5}$ C. Matt Guilliams, ${ }^{6}$ \\ Kristen E. Hasenstab-Lehman, ${ }^{7}$ Hartmut H. Hilger, ${ }^{8}$ James S. Miller, ${ }^{9}$ Moritz Mittelbach, ${ }^{10}$ Mare Nazaire, ${ }^{7}$ \\ Massimo Nepi, ${ }^{11}$ Daniele Nocentini, ${ }^{11}$ Dietrich Ober, ${ }^{12}$ Richard G. Olmstead, ${ }^{13}$ Federico Selvi, ${ }^{14}$ \\ Michael G. Simpson, ${ }^{15}$ Karel Sutorý, ${ }^{16}$ Benito Valdés, ${ }^{17}$ Genevieve K. Walden ${ }^{18}$ \& Maximilian Weigend ${ }^{1}$ \\ 1 Universität Bonn, Nees-Institut für Biodiversität der Pflanzen, Meckenheimer Allee 170, 53115 Bonn, Germany \\ 2 Universidad de Chile, Departamento de Silvicultura y Conservación de la Naturaleza, Santiago, Chile \\ 3 Università di Firenze, Museo di Storia Naturale, sezione botanica "Filippo Parlatore", Via G. La Pira 4, 50121 Florence, Italy \\ 4 Jodrell Laboratory, Kew Botanical Gardens, Richmond, Surrey, TW9 3DS, U.K. \\ 5 Department Biologie, Systematische Botanik und Mykologie, GeoBio-Center, Ludwig-Maximilians-Universität München, \\ Menzinger Str. 67, 80638 Munich, Germany \\ 6 Santa Barbara Botanic Garden, 1212 Mission Canyon Road, Santa Barbara, California 93105, U.S.A. \\ 7 Rancho Santa Ana Botanic Garden, 1500 N College Ave, Claremont, California 91711, U.S.A. \\ 8 Freie Universität Berlin, Institut für Biologie-Botanik, Altensteinstraße 6, 14195 Berlin, Germany \\ 9 Missouri Botanical Garden, P.O. Box 299, St. Louis, Missouri 63166-0299, U.S.A. \\ 10 Ruhr-Universität Bochum, Geobotanik - Gebäude ND 03/170, Universitätsstrasse 150, 44780 Bochum, Germany \\ 11 Biodiversity and Conservation Network (BIOCONNET), Department of Environmental Sciences, University of Siena, \\ via P.A. Mattioli 4, 53100 Siena, Italy \\ 12 Botanisches Institut und Botanischer Garten, Universität Kiel, 24098 Kiel, Germany \\ 13 Department of Biology, Box 355325, University of Washington, Seattle, Washington 98195, U.S.A. \\ 14 Università di Firenze, Dipartimento di Scienze delle Produzioni Agroalimentari e dell'Ambiente (DISPAA), Laboratorio di \\ Botanica, P.le delle Cascine 28, 50144 Florence, Italy \\ 15 Department of Biology, San Diego State University, San Diego, California 92182, U.S.A. \\ 16 Department of Botany, Moravian Museum, Hviezdoslavova 29a, 627 00, Brno, Czech Republic \\ 17 Universidad de Sevilla, Departamento de Biología Vegetal y Ecología, Avda. Reina Mercedes s/n, 41012 Sevilla, Spain \\ 18 Department of Integrative Biology, University of California, Berkeley, California 94720, U.S.A. \\ Authors for correspondence: Federico Luebert, fluebert@uni-bonn.de; MaximilianWeigend, mweigend@uni-bonn.de \\ ORCID FL, http://orcid.org/0000-0003-2251-4056; LC, http://orcid.org/0000-0002-9332-704X; CMG, http://orcid.org/0000-0003-3919-8432; \\ MNe, http://orcid.org/0000-0002-6765-897X; FS, http://orcid.org/0000-0002-3820-125X; MW, http://orcid.org/0000-0003-0813-6650 \\ DOI http://dx.doi.org/10.12705/653.5
}

\begin{abstract}
The Boraginales are now universally accepted as monophyletic and firmly placed in Lamiidae. However, a consensus about familial classification has remained elusive, with some advocating recognition of a single, widely variable family, and others proposing recognition of several distinct families. A consensus classification is proposed here, based on recent molecular phylogenetic studies, morphological characters, and taking nomenclatural stability into consideration. We suggest the recognition of eleven, morphologically well-defined and clearly monophyletic families, namely the Boraginaceae s.str., Codonaceae, Coldeniaceae fam. nov., Cordiaceae, Ehretiaceae, Heliotropiaceae, Hoplestigmataceae, Hydrophyllaceae, Lennoaceae, Namaceae, and Wellstediaceae. Descriptions, synonomy, a taxonomic key, and a list of genera for these eleven families are provided, including the new family Coldeniaceae (monogeneric) and Namaceae (segregated from Hydrophyllaceae and comprising Nama, Eriodictyon, Turricula, and Wigandia), the latter necessitating a revised circumscription of a more morphologically coherent Hydrophyllaceae.
\end{abstract}

Keywords angiosperms; Boraginaceae; Boraginales; classification; family; plant taxonomy

\section{INTRODUCTION}

Boraginales are a plant group of the Lamiidae comprising about 125 genera and around 2700 species of herbs, shrubs, trees and lianas distributed worldwide. The classification of this order has changed dramatically over time, especially since molecular data and phylogenetic analyses became available. The purpose of this paper is to provide a familial classification of the order Boraginales compatible with phylogenetic data and adequately reflecting the morphological heterogeneity within this group. The core of the species of Boraginales belongs to the family Boraginaceae in the traditional sense.

Received: 15 May 2015 | returned for (first) revision: 23 Jun 2015 | (last) revision received: 15 Feb 2016 | accepted: 15 Feb 2016 || publication date(s): online fast track, n/a; in print and online issues, 24 Jun 2016 || (C) International Association for Plant Taxonomy (IAPT) 2016 
Boraginaceae in this traditional sense (Candolle, 1845; Bentham \& Hooker, 1876; Gürke, 1893; Engler, 1898; Pilger \& Krause, 1915) were subdivided into five subfamilies, namely Boraginoideae, Cordioideae, Ehretioideae, Heliotropioideae and Wellstedioideae. In pre-molecular times most scientists accepted this circumscription of Boraginaceae (e.g., Chadefaud \& Emberger, 1960; Melchior, 1964b; Takhtajan, 1980, 1997; Cronquist, 1981, 1988; Thorne, 1992), although some authors recognized one or the other subfamily at the family level. For example, Svensson (1925) and Di Fulvio (1978) removed Cordioideae, Heliotropioideae and Ehretioideae to Heliotropiaceae based on embryological studies, while Merxmüller (1960), Dahlgren (1980), and Takhtajan (1987) treated Wellstedioideae at the family level as Wellstediaceae. Conversely, Hoplestigmataceae, Hydrophyllaceae, and Lennoaceae were generally accepted as distinct families. However, the close relationships of these taxa to traditional Boraginaceae has been widely acknowledged by several authors (e.g., Jussieu, 1789; Baillon, 1891; Peter, 1893; Svensson, 1925; Chadefaud \& Emberger, 1960; Melchior, 1964a, c; Takhtajan, 1980; Cronquist, 1981, 1988). For example, Baillon (1891) defined the Boraginaceae as comprising nine series, which included both Boraginaceae and Hydrophyllaceae in their traditional circumscriptions. Chadefaud \& Emberger (1960) considered Boraginaceae, Hoplestigmataceae, Hydrophyllaceae, and Lennoaceae to form a natural group within the order Tubiflorales. Takhtajan (1980) included these same families in the suborder Boraginineae.

On the other hand, three groups historically associated to Boraginaceae have been clearly shown to be only distantly related: Thorne (1992) placed Tetrachondraceae in Boraginineae, and Takhtajan (1997) placed them in the order Boraginales. After Savolainen \& al. (2000) demonstrated that Tetrachondraceae are phylogenetically closer to Lamiales, the remainder of the families was reunited in the order Boraginales (Takhtajan, 2009; Reveal \& Chase, 2011). Monogeneric Vahliaceae have been sometimes been regarded as close relatives of Boraginales (e.g., Bremer \& al., 2002), but more comprehensive molecular phylogenetic studies indicate that this family is more closely related either to Solanales (Savolainen \& al., 2000; RefulioRodríguez \& Olmstead, 2014) or Lamiales (Weigend \& al., 2014). Phylogenetic studies further demonstrate that Hydrolea $\mathrm{L}$., previously treated in the Hydrophyllaceae, is more closely related to Solanales (Cosner \& al., 1994; Soltis \& al., 2000). Historical circumscriptions of Boraginaceae and related families by different authors are summarized in Appendix 1.

Phylogenetic studies demonstrate that Boraginaceae in the traditional sense are paraphyletic with respect to Hoplestigmataceae, Hydrophyllaceae, and Lennoaceae, and that Hydrophyllaceae in the traditional sense are not monophyletic (Olmstead \& al., 1993; Ferguson, 1999; Gottschling \& al., 2001; Nazaire \& Hufford, 2012; Refulio-Rodríguez \& Olmstead, 2014; Weigend \& al., 2014). Codon L., traditionally accepted in Hydrophyllaceae, is the sister group to a clade including Wellstedia Balf.f. (= Wellstedioideae) and Boraginaceae s.str. (= Boraginoideae), and has been segregated to the family Codonaceae (Weigend \& Hilger, 2010; Weigend \& al., 2014). The remaining genera of the traditional Hydrophyllaceae (after removal of Hydrolea) form two distinct clades within Boraginales (Ferguson, 1999; Refulio-Rodríguez \& Olmstead, 2014; Weigend \& al., 2014) (Fig. 1). The first clade includes the type genus of the family (Hydrophyllum L.) and the majority of the genera, while the second comprises Eriodictyon Benth., Nama L., Turricula J.F.Macbr., and Wigandia Kunth. These clades are successive sister groups to a clade comprising Coldenia L., Cordiaceae, Ehretiaceae, Heliotropiaceae, Hoplestigmataceae, and Lennoaceae (Fig. 1).

Boraginales, in this revised circumscription (i.e., after exclusion of Vahliaceae, Hydroleaceae, and Tetrachondraceae and inclusion of Hoplestigmataceae, Hydrophyllaceae, and Lennoaceae), is a well-supported monophyletic group in Lamiidae (Gottschling \& al., 2001; Bremer \& al., 2002; Moore \& Jansen, 2006; Luebert \& al., 2011a; Soltis \& al., 2011; Nazaire \& Hufford, 2012; Cohen 2014; Refulio-Rodríguez \& Olmstead, 2014; Weigend \& al., 2014). However, Boraginales have been variously resolved as sister to Lamiales (Soltis \& al., 2011; Refulio-Rodríguez \& Olmstead, 2014), Solanales (Weigend $\&$ al., 2014), Gentianales (Stull \& al., 2015), or Solanales+ Gentianales (Moore \& al., 2010), always with low to moderate support only.

Recent phylogenetic studies provide clear insights into the major lineages of Boraginales, and these are summarized in Fig. 1. Most recent authors recognize several distinct families in Boraginales (e.g., Gottschling \& al., 2001; Hilger \& al., 2005; Luebert \& Wen, 2008; Weigend \& Hilger, 2010; Luebert \& al., 2011a; Cohen, 2014; Refulio-Rodríguez \& Olmstead, 2014; Weigend \& al., 2014). Accepting the principle of monophyly in classification, the advantages of recognizing different families within Boraginales versus lumping all clades into a single family Boraginaceae s.l. include the ease of morphological recognition, moderate group size, and increased nomenclatural stability (Backlund \& Bremer, 1998; Vences \& al., 2013).

The Angiosperm Phylogeny Group classifications (APG, 1998; APG II, 2003; APG III, 2009) opted for recognizing a single family Boraginaceae s.l., which was classified as an unplaced family (i.e., not placed in an order) within the euasterids I (APG, 1998; APG II, 2003) or within the lamiids (APG III, 2009). This was done in the absence of a clear understanding of the phylogenetic interrelationships among clades included within Boraginales and their relationships to other orders. This option has the drawback of reducing the families Hoplestigmataceae, Hydrophyllaceae and Lennoaceae to subfamily or tribe level. These families have a long history of recognition, including past taxonomic treatments (e.g., Melchior, 1964a, c; Yatskievych \& Mason, 1986), major Floras (e.g., Aubréville, 1959; Hepper, 1963; Howard, 1989; Liogier, 1994; Sullivan, 2001; Yatskievych, 2001, 2012; Hofmann, 2004; Sklenáŕ \& al., 2005; Ricketson, 2012; Cecchi \& Selvi, 2015a) and angiosperm classification systems (e.g., Cronquist, 1988; Heywood \& al., 2007; Takhtajan, 2009).

Some recent treatments have followed a broad circumscription of Boraginaceae (i.e., including traditional Boraginaceae, Hoplestigmataceae, Hydrophyllaceae, and Lennoaceae) as recommended by the APG systems (e.g., Judd \& al., 2008; Mabberley, 2008; Stapf, 2009; Simpson, 2010; Reveal, 2011, 
2012; Acevedo-Rodríguez \& Strong, 2012; Nazaire \& Hufford, 2012; Walden \& Patterson, 2012; Walden \& al., 2014). However, most recent studies of Boraginales or its subgroups favor the recognition of several families (Gasparino \& Vitorino da Cruz Barros, 2009; Melo \& al., 2009; Véliz Pérez \& al., 2009; Luebert \& al., 2010, 2011a, b; Melo \& Semir 2010; Stapf \& al., 2010; Weeks \& al., 2010; Weigend \& Hilger, 2010; CamposRíos \& Chiang Cabrera, 2012; Miller, 2012, 2013a, b; Stutzman \& al., 2012; Luebert, 2013; Stapf \& Silva, 2013a, b; Tölke \& al., 2013; Cohen, 2014; Gottschling \& al., 2014a, b; RefulioRodríguez \& Olmstead, 2014; Weigend \& al., 2014; Irimia \& al., 2015; Liu \& al., 2015; Luebert \& Hilger, 2014). This view has been adopted in several recent floristic and taxonomic treatments, such as Flora critica d'Italia (Cecchi \& Selvi, 2015a, b), Flora Mesoamericana (Davidse \& al., 2012), Families and Genera of Vascular Plants (Kadereit \& Bittrich, 2016), Angiosperm Phylogeny Website (Stevens, 2001-), and has recently been incorporated in the most important German botanical textbook (Kadereit \& al., 2014). Flora of North America (http:// floranorthamerica.org/Review/under-prod-15, accessed 21 Jul
2015), Flora of Nepal (http://padme.rbge.org.uk/floraofnepal/, accessed 22 Sep 2015), and Flora of Ecuador (http://www2. dpes.gu.se/project/ecuador/, accessed 22 Sep 2015) plan to publish their treatments of Boraginales with several constituent families. Although we acknowledge that views may differ, we believe that recognizing Boraginaceae s.l. does not serve nomenclatural stability, reducing several long-recognized families to subfamilies.

Historically, the coherence of Boraginaceae was primarily based on the presence of four one-seeded compartments in the fruit, separating into four nutlets in the most typical case (Bentham \& Hooker, 1876; Gürke, 1893). However, it has now been shown that this fruit morphology evolved independently in the two major clades of Boraginales from ancestors with many-seeded, capsular fruits (Weigend \& al., 2013, 2014). A more detailed study (Fig. 2) shows that the development of superficially similar fruits with four separate nutlets follows different trajectories and therefore does not represent a case of phylogenetic homology (Fig. 2). Capsular fruits, as characteristic of polyphyletic Hydrophyllaceae appear to represent apomorphic ] plesiomorphic

1 Gynoecium bicarpellate 2 Fruit a capsule

3 Fruit dehiscence loculicidal 4 Habit spiny

5 Calyx lobes $10-12$

6 Corolla lobes 10-12

7 Nectary chamber present

8 Ovules $\leq 4$

9 Flower tetramerous 10 Fruit a flattened capsule 11 Placentation apical

12 Fruit dehiscence septicidal 13 Style gynobasic

14 Fruit of nutlets

15 Testa transfer cells present

16 Plants herbaceous

17 Endocarp multi-layered

18 Ovules $\leq 4$

19 Style-stigma complex present 20 Parasites

21 Carpels $\geq 5$

22 Fruit dehiscence circumscissile

23 Adventitious roots present

24 Flowers tetramerous

25 Corolla lobes $\geq 10$

26 Stamens $\geq 20$

27 Stigmatic branches 4

28 Endocarp undivided

29 Cotyledons plicate

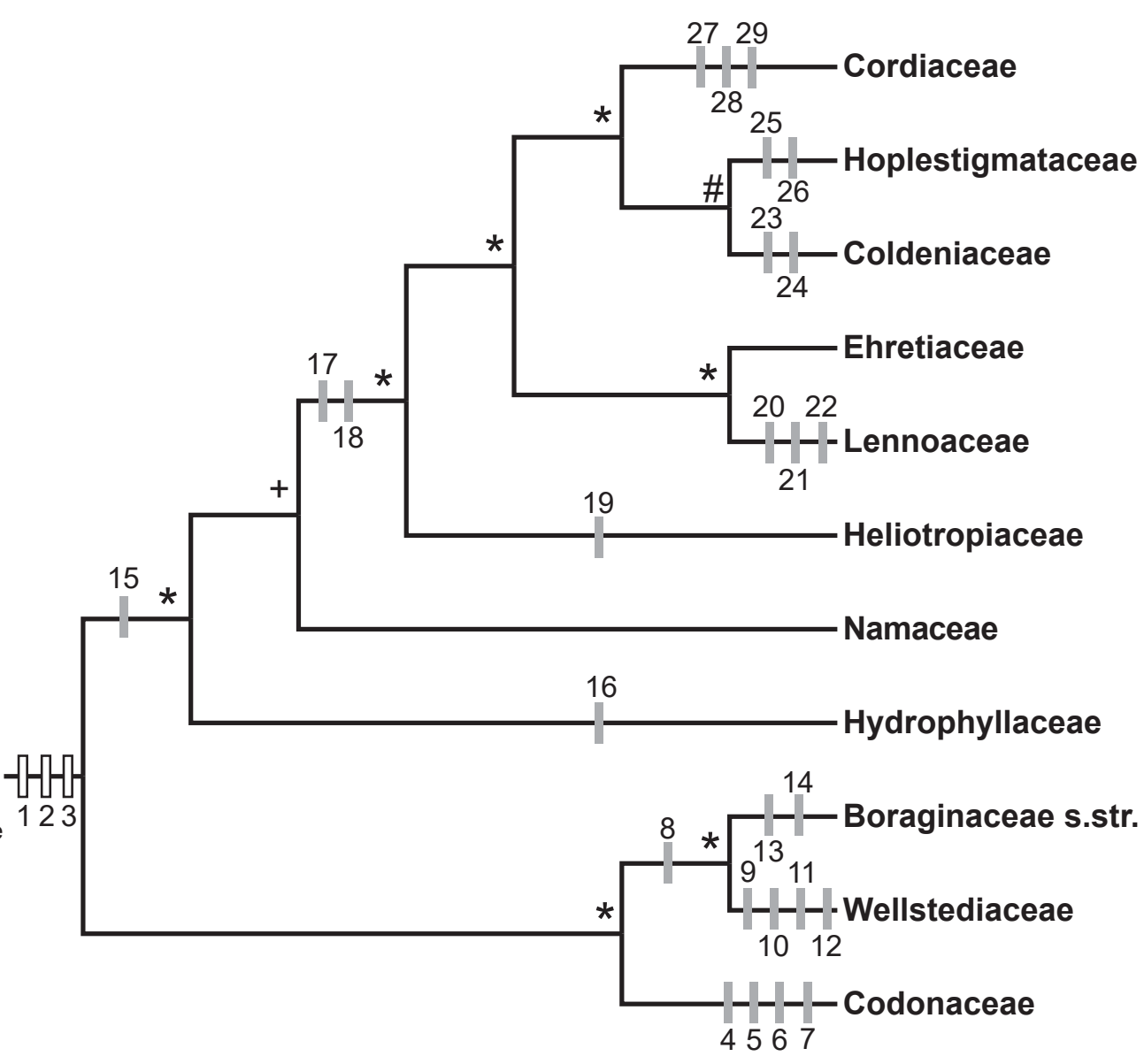

Fig. 1. Major clades of the Boraginales based on Refulio-Rodríguez \& Olmstead (2014) and Weigend \& al. (2014). The clade with + is well supported (Bayesian posterior probability $>0.95$, maximum likelihood bootstrap value $>80$ ) only in Refulio-Rodríguez \& Olmstead (2014). The clade with \# is moderately supported (Bayesian posterior probability $=0.9$, maximum likelihood bootstrap value $=60$ ) only in Weigend \& al. (2014) and is not present in Refulio-Rodríguez \& Olmstead (2014). Clades with * indicate well-supported groups (Bayesian posterior probabilities $>0.95$, maximum likelihood bootstrap values > 80) in the phylogenies of Refulio-Rodríguez \& Olmstead (2014) and Weigend \& al. (2014). Putative apomorphic character states for major clades are indicated. These are not based on a explicit ancestral state reconstruction. 

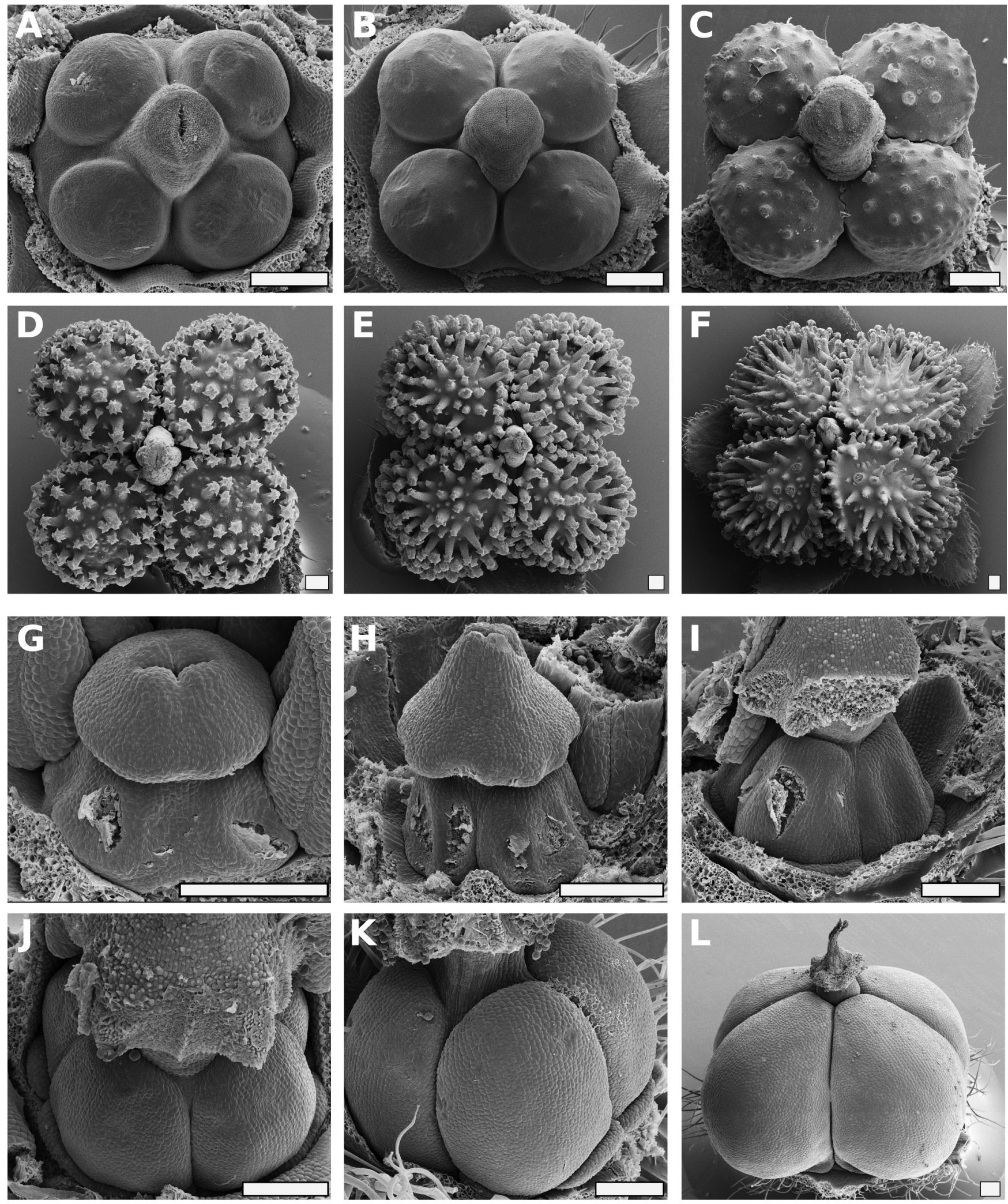

Fig. 2. Flower and fruit development in Cynoglossum australe R.Br. (A-F, Boraginaceae s.str., Joßberger 062, BONN) and Heliotropium europaeum L. (G-L, Heliotropiaceae, Lobin \& Weigend 233-14, BONN). The species depicted correspond to the two major clades of Boraginales, in which nutlets evolved independently. In the Boraginaceae s.str., the four nutlets become distinct very early in ontogeny (A), with the style gynobasically inserted (A-C); fruit develops into four nutlets (D-F). In Heliotropiaceae, the ovary is essentially undivided at anthesis (G), with the style apically inserted on the ovary (H-K); nutlets become distinct once fruit maturation starts (J-K); mature fruit may overtop the base of the style (L). — All scale bars = $200 \mu \mathrm{m}$. Material cultivated at the Botanical Garden in Bonn (accession numbers 37351 and 35823). Pictures by Hans Jürgen Ensikat. 
the plesiomorphic condition for both clades (Fig. 1). Thus, no fruit morphological synapomorphy for Boraginales can be recognized. In the face of this evidence, the most important historical argument for maintaining traditional Boraginaceae and Hydrophyllaceae as separate entities, or even as a single broadly circumscribed family (Boraginaceae s.l.), is eliminated and an updated classification appears even more justified.

Based on phylogenetic data (Refulio-Rodríguez \& Olmstead, 2014; Weigend \& al., 2014; Stull \& al., 2015), the two major clades of the Boraginaceae s.l. [Boraginales] consist of: (1) Codonaceae+Wellstediaceae + Boraginaceae s.str.; and (2) Hydrophyllaceae + Namaceae + Heliotropiaceae + Lennoaceae + Ehretiaceae + Coldenia + Hoplestigmataceae + Cordiaceae (Fig. 1). Thus, one option is to recognize each of the two clades at the family level. However, this solution would have the same drawbacks as recognition of Boraginaceae s.l., given that neither of the two major clades has been named at any taxonomic level in previous classifications, so this would cause maximal nomenclatural disruption.

Lennoaceae are here recognized at family level, because of the combination of a parasitic life form, polymerous perianth and a unique fruit morphology (circumscissile capsule enclosing pyrenes; Yatskievych \& Mason, 1986) (Fig. 1). The recognition of Cordiaceae (see Appendix 1) is based on multiple apomorphies, such as the presence of four stigmatic branches, an undivided endocarp, and plicate cotyledons (Gottschling $\&$ al., 2005).

The largely woody lineages related to Cordia L. and Ehretia P.Browne comprise a monophyletic group and could be united to form Ehretiaceae s.l. (Kadereit \& Bittrich, 2016; with Lennoaceae separate). However, monophyly of Ehretiaceae s.l. is verified only by molecular data at present, as no morphological apomorphy has been proposed for this clade (Fig. 1). This solution would thus be inconsistent with the explicit aim of recognizing morphologically well-circumscribed families. Alternatively, based on the presence of a multilayered endocarp in Heliotropiaceae+Lennoacea+Ehretiaceae+ Coldenia + Hoplestigmataceae + Cordiaceae, these could be united into a more broadly defined Heliotropiaceae s.l. This has not been proposed before and would therefore be a major change in classification.

The authors of this paper favor the recognition of eleven easily recognizable and morphologically well-defined monophyletic families (i.e., the major clades of Fig. 1, see Table 1). These entities are characterized mostly by apomorphic characters (Fig. 1). This classification represents only a minimal disruption of nomenclatural stability in mostly recognizing taxa with valid family names already in use; all but one have valid names at the family level. Taxonomic novelties are the description of the monogeneric Coldeniaceae fam. nov. (Coldenia alone), and the splitting of the Hydrophyllaceae into two families (Refulio-Rodríguez \& Olmstead, 2014; Weigend \& al., 2014), with Namaceae accommodating the genera Eriodictyon, Nama, Turricula, and Wigandia.

The consensus for this system was achieved during an international meeting on Boraginales in 2014 in Bonn, where most of the authors attended and discussed different alternatives of classification. All participants in that meeting favored a classification of Boraginales into several separate families. Further coauthors were invited to participate in this proposal after a draft classification had been formulated by the participants. One case was left open to discussion, namely the split of Lennoaceae, Ehretiaceae, Coldeniaceae, Hoplestigmataceae, and Cordiaceae. The opinion of the specialists in this group was then adopted.

The classification of Boraginales as outlined here reflects the current knowledge about the phylogenetic relationships in the group and provides a familial classification for the order, lacking in recent angiosperm-wide classifications (APG, 1998; APG II, 2003; APG III, 2009; Reveal, 2011, 2012; Reveal \& Chase, 2011). This classification attempts to fulfill APG III (2009) criteria for recognition of taxa at the family level as proposed by Backlund \& Bremer (1998).

There are two instances in which phylogenetic results currently available are not entirely conclusive. First, the relationships of Hydrophyllaceae and Namaceae (Fig. 1) to the other lineages of Boraginales are not fully resolved. ITS phylogenies recover Hydrophyllaceae s.l. (excl. Codon) as monophyletic (Gottschling \& al., 2001; Nazaire \& Hufford, 2012), with the Hydrophyllaceae s.str. sister to Namaceaeae with moderate to poor support. Studies using plastid data resolve these two clades as successive sister groups to Heliotropiaceae+Lennoacea + Ehretiaceae + Coldeniaceae + Hoplestigmataceae + Cordiaceae, albeit not always with high support (Refulio-Rodríguez \& Olmstead, 2014 based on chloroplast atpB, matK, ndhF, psbBTNH, rbcL, rps4, rps16, trnL-F, trnV-atpE, and mitochondrial rps3; Weigend \& al., 2014, based on chloroplast $n d h F$, $r b c L, r p s 16, t r n L-F)$. The present proposal is compatible with both plastid and ITS phylogenies. The key morphological character of the traditional Hydrophyllaceae, the capsular fruit, is plesiomorphic, so the subdivision is not in conflict with morphology, but neither does morphology provide strong support for their separation (Table 1).

The second uncertainty is the status of Lennoaceae and its relationship to Ehretiaceae. Morphologically, the Ehretiaceae are readily circumscribed with diagnostic features including a bifid style with two stigmatic branches and usually drupaceous fruits with four pyrenes (less commonly two 2-seeded pyrenes, or rarely an entire endocarp). However, monophyly has been questioned because molecular data suggest that Lennoaceae may be nested in Ehretiaceae (Gottschling \& al., 2001, 2014a; Nazaire \& Hufford, 2012; Weigend \& al., 2014). Additional data are required to resolve detailed relationships of Lennoaceae and Ehretiaceae. Lennoaceae are therefore here retained as historically recognized.

\section{- FORMAL TAXONOMY}

Boraginales Juss. ex Bercht. \& J.Presl, Přir. Rostlin: 244. 1820.

= Asperifoliae H.Rose, Elem. Bot.: 56. 1775.

$=$ Cordiales Mart., Consp. Regn. Veg.: 23. 1835.

= Ehretiales Mart., Consp. Regn. Veg.: 22. 1835.

$=$ Hydrophyllales Mart., Consp. Regn. Veg.: 22. 1835.

$=$ Echiales Lindl. in Penny Cyclop. 10: 128. 1838. 
Annual or perennial herbs, shrubs, trees, lianas or holoparasitic plants. Leaves simple, alternate or opposite, estipulate. Flowers in scorpioid inflorescences, rarely solitary. Flowers hermaphroditic or unisexual, actinomorphic or rarely zygomorphic, hypogynous. Perianth heterochlamydeous, (4-)5(-15)-merous, calyx lobes free nearly to the base to united nearly completely, corolla usually united for at least half of its length. Androecium composed of (4-)5(-12 or 20-35) stamens, filaments usually united with corolla tube, anthers bilocular. Gynoecium with style insertion apical or gynobasic, style 1, rarely 2 or 4 stylodia, stigma undivided or with 2 or 4 branches. Ovary 2-carpellate or rarely 5-16-carpellate. Fruit a capsule, drupe, nut or (1-)4 nutlets, dehiscence loculicidal, septicidal, eremocarpic (see Glossary), schizocarpic, or indehiscent. Ovary locules 1-4(10-32). Ovules per locule 1-many. Placentation axile, parietal or apical. Seeds per fruit 1-many. Endosperm copious, scanty or absent.

Eleven families with 125 genera and around 2700 species.

\section{Key to the families of Boraginales}

1. Plants without chlorophyll, leaves reduced to cataphylls; ovary 5-16-carpellate, 10-32-locular by secondary subdivision; fruit a depressed capsule with circumscissile dehiscence.

Lennoaceae

1. Plants with chlorophyll, leaves with well-developed lamina; ovary 2-carpellate, 1-locular or 2-4-locular by secondary subdivision; fruit with 1-4 pyrenes, or 4-seeded, but undivided, or capsular with loculicidal or septicidal dehiscence. ....

2. Ovary subdivided into (1-)4(-8) uni-ovulate eremocarps in flower developing into corresponding number of individual nutlets; style insertion gynobasic ....

Boraginaceae s.str.

2. Ovary entire in flower, developing into a capsule or a (dry or succulent) drupe, or separating into 2-4 individual nutlets at maturity; style insertion apical.

3. Stems and leaves with stiff, white spines; calyx and corolla 10-12-merous, calyx segments unequal; fruit a manyseeded capsule ............................ Codonaceae

3 Stems and leaves not spinose, but sometimes setose or with axillary thorns (Rochefortia Sw.); flowers usually 4-5-merous (if more, as in Hoplestigma, then fruit drupaceous); calyx segments equal or subequal............ 4

4. Fruit a laterally flattened, obcordate capsule with 1-2 seeds; flowers always 4-merous .......... Wellstediaceae

4. Fruit ovoid, if capsular never laterally flattened and with $4-\infty$ seeds; flowers usually 5 -merous, if tetramerous fruits then spiny nutlets.................................. 5

5. Fruit a capsule with $4-\infty$ seeds, sometimes fewer by abortion

5. Fruit indehiscent or schizocarpic, fleshy or dry, often subdivided into mericarps, 4-seeded, sometimes fewer by abortion ........................................... 7

6. Shrubs or small trees, or herbaceous (only Nama); leaves cauline, simple; stylodia 2, or style united for $3 / 4$ of its length with two stigmatic branches

Namaceae
6. Annual or perennial herbs, leaves cauline and basal, rarely basal or cauline only, simple or-more commonly-variously divided to bipinnate; style 1 with 2 stigmatic branches

Hydrophyllaceae

7. Stigma not terminal, style undivided, terminal with a conical stigmatic head having a basal ring-shaped stigma and a sterile, sometimes 2-lobed apex (style-stigma complex); flowers usually in dense, scorpioid, bracteate or ebracteate monochasia. ...

Heliotropiaceae

7. Stigma(s) terminal, style entire to deeply divided; flowers not in scorpioid monochasia, often in repeatedly dichasial inflorescences .......................................... 8

8. Gynoecium with 4 stigmatic branches (if 2 , then fruit completely enclosed in accrescent calyx); ovules orthotropous; cotyledons plicate ......................... Cordiaceae

8. Gynoecium with 1-2 stigmatic branches; fruit not enclosed in accrescent calyx (except in Bourreria grandicalyx J.S.Mill. \& Sirot); ovules anatropous; cotyledons not plicate .............................................. 9

9. Stamens $20-35$ in three irregular series.

Hoplestigmataceae

9. Stamens 4 or 5 in one series ....................... 10

10. Flowers 5-merous; mostly perennial, woody plants without adventitious roots ........................ Ehretiaceae

10. Flowers 4-merous; annual plants with adventitious roots

Coldeniaceae

\section{Family descriptions}

Note: In the following descriptions, apomorphic characters of the families are highlighted in bold (compare Fig. 1).

Boraginaceae Juss., Gen. Pl.: 128. 1789, nom. cons. - Type: Borago L.

= Buglossaceae Hoffmanns. \& Link, Fl. Portug. 1: 63.1809 ("Buglossinae").

= Anchusaceae Vest, Anleit. Stud. Bot.: 274, 302. 1818 ("Anchusoideae").

$=$ Cerinthaceae Bercht. \& J.Presl, Přir. Rostlin: 244. 1820.

= Onosmaceae Martinov, Tekhno-Bot. Slovar: 437. 1820

(“Onosmoides").

= Asperifoliaceae Rchb., Consp. Regn. Veg.: 89, 118. 1829.

= Echiaceae Raf., Fl. Tellur. 2: 61. 1837 ("1836") (“Echidia").

= Cynoglossaceae Döll, Rhein. Fl.: 406. 1843 .

Annual to perennial herbs, rarely shrubs or trees, tap-rooted or rhizomatous, indumentum pubescent, sericeous or hispid. Leaves alternate, entire, sessile or petiolate, lamina mostly (ob-) ovate to elliptical. Inflorescences terminal or axillary, monochasial or dichasial, usually scorpioid and contracted into boragoids (see Glossary), sometimes congested into terminal "heads" or reduced to single flowers. Flowers pentamerous, bisexual; calyx united nearly to apex or divided nearly to base, lobes mostly narrowly ovate-acuminate, sometimes linear or broadly ovateacuminate with a cordate base, with a more or less pronounced scabrid to lanate or uncinate indumentum, aestivation apert to valvate; corolla white, yellow, pink or often blue, sympetalous, 
hypocrateriform, infundibuliform to cylindrical or campanulate, lobes variously erect to spreading, aestivation imbricate or contorted; stamens 5 , rarely fewer, filaments various, short to very long, anthers deeply included to exserted; gynoecium bicarpellate, ovary 4-locular by secondary subdivision at early anthesis, style gynobasic, often with pyramidal to subulate gynobase, stigma capitate to bilobate; nectar disc present at ovary base. Fruit with (1-2)-4 1-seeded nutlets, rarely of two 2-seeded nutlets, these variously modified, often dorsiventrally compressed, with a marginal wing or ring, often glochidiate.

Around 90 genera (Appendix 2) with some 1600-1700 species of worldwide distribution, especially in extratropical zones.

Major clades within Boraginaceae s.str. are relatively wellresolved, with Echiochileae sister to the rest, where Boragineae and Lithospermeae form a clade, which is sister to Cynoglosseae s.l. (Weigend \& al., 2013). The family is readily distinguished by its mostly herbaceous habit, generally scorpioid inflorescences, gynobasic style, and four nutlets sometimes ornamented with glochidiate spines. Boraginaceae have been variously circumscribed, ranging from an inclusive taxon encompassing the whole order Boraginales to a family defined in its most strict sense as accepted here (see Appendix 1).

Codonaceae Weigend \& Hilger in Phytotaxa 10: 27. 2010 Type: Codon L.

$=$ Codonoideae Retief \& A.E.van Wyk in Bothalia 35(1): 79. 2005.

$=$ Codoneae Nazaire \& L.Hufford in Syst. Bot. 37: 778. 2012.

Subperennial or perennial, densely branched, spiny shrublets with tap-roots, indumentum of white spines, stiff unicellular trichomes and 2-5-celled gland-tipped trichomes. Leaves alternate, entire, petiolate, lamina ovate, adaxially densely spiny, abaxially with spines only on the very prominent midvein. Inflorescences terminal, frondose-bracteose, initially scorpioid, later straight monochasial, rarely reduced to a single terminal flower. Flowers with 10-12 perianth elements, bisexual; calyx divided nearly to base, lobes unequal in width, narrow and wide calyx lobes alternating, densely spinose and pubescent, aestivation valvate; corolla white or yellow, sympetalous, campanulate to saucer-shaped, lobes half-erect to spreading, aestivation imbricate; stamens 10-12, filaments basally pubescent and each connected to corolla tube by septa forming a nectary chamber, anthers exserted; gynoecium bicarpellate, ovary nearly bilocular by deeply intruding placentae, style terminal, stigmatic branches 2, stigma punctiform; nectar disc present at ovary base. Fruit a dry, bivalved capsule, loculicidal, seeds numerous.

One genus (Codon) and two species endemic to southwestern Africa. Codon is readily recognized by its peculiar spines, flowers with 10-12 perianth parts, bivalvate, capsular fruits, and the presence of a nectary chamber. Constance (1963) recommended that Codon "should constitute a family of its own". Codon was identified as a clade separate from Hydrophyllaceae (Ferguson, 1999), and as a distinct lineage in the Boraginaceae at subfamily (Retief \& Van Wyk, 2005) and tribal level (Nazaire \& Hufford, 2012), and was segregated as Codonaceae (Weigend \& Hilger, 2010).
Coldeniaceae J.S.Mill. \& Gottschling, fam. nov. - Type: Coldenia L.

Procumbent annual herbs with slender, branched stems, often with adventitious roots, indumentum densely, softly pubescent with simple, unicellular white trichomes. Leaves numerous, alternate, shortly petiolate, fasciculate, small, asymmetrical, bullate, margin serrate to crenate, venation pinnate with secondary veins deeply immersed and ending in sinuses of the crenations, obovate in outline, pubescent only between veins adaxially and across the entire surface abaxially. Inflorescences axillary, frondose monochasia, these often elongating and anthocladal (see Glossary). Flowers tetramerous, bisexual, minute; calyx lobes free nearly to base, ovate, long-pubescent, aestivation valvate; corolla white or yellowish, sympetalous, tube urceolate, glabrous, lobes oblong, porrect, aestivation imbricate; stamens 4, filaments short, adnate to the corolla tube, anthers deeply included; gynoecium bicarpellate, ovary ovoid, densely covered with moniliform trichomes, style terminal, apically with two minute, papillose stylodia, stigma capitate; nectar disc possibly present at ovary base. Fruit small, dry, broadly pear-shaped in lateral view, deeply 4-lobed, apically beaked from sterile apex of ovary, coarsely and irregularly pubescent, sparsely and irregularly verrucose to spinose, largely enclosed into strongly accrescent calyx, tardily (post-dispersal) separating into four 1-seeded, oblique pear-shaped nutlets, sterile chambers absent, pericarp weakly lignified and cork-like in structure.

One species (Coldenia procumbens L.) widespread in the Old World tropics and introduced elsewhere. Long considered congeneric with Tiquilia Pers. in the Ehretiaceae (e.g., Gray, 1862; Bentham \& Hooker, 1976; Baillon, 1891; Gürke, 1893; Johnston, 1924; Chadefaud \& Emberger, 1960; Takhtajan, 1987). Richardson (1976) demonstrated that the two genera are distantly related based on morphology, and this is supported by recent molecular studies (Gottschling \& al., 2005; Moore \& Jansen, 2006; Weigend \& al., 2014). Coldenia had been provisionally included in Cordiaceae (Miller \& Gottschling, 2007). However, Coldenia is distinct in its procumbent annual habit, frondose inflorescences, flat (not plicate) cotyledons, and fruits separating in four apically beaked and spinose nutlets.

Cordiaceae R.Br. ex Dumort., Anal. Fam. Pl.: 20, 25. 1829, nom. cons. - Type: Cordia L.

= Sebestenaceae Vent., Tabl. Règn. Vég. 2: 380. 1799 ("Sebestenae").

$=$ Cordieae Dumort., Anal. Fam. Pl.: 25. 1829.

$=$ Cordioideae Beilschm. in Flora 16(1, Beibl.): 69, 106. 1833 (“Cordiaceae", p. 69; "Cordieae", p. 106).

Trees, shrubs, or rarely lianas, indumentum often pubescent with stiff trichomes, sometimes hispid or glabrescent. Leaves alternate, rarely subopposite, entire, petiolate, lamina variable in shape. Inflorescences mostly terminal, basically with dichasial or monochasial paracladia, but also capitate, spicate or very shortly cymose umbellate to globose, sometimes corymbo-thyrsoid. Flowers pentamerous, rarely tetramerous, rarely more perianth elements, bisexual and often distylous, occasional unisexual and dioecious; calyx united in a tube, 
tubular to campanulate, lobes lanceolate to ovate, aestivation valvate; corolla white, or rarely yellow, sympetalous, tubular to campanulate or rotate, lobes distinct or not, erect to spreading, aestivation imbricate; stamens $(4-) 5(-15)$, filaments generally adnate to the corolla tube, at least at the base, sometimes puberulent at the point of insertion, anthers usually exerted; gynoecium bicarpellate, ovary tetralocular from secondary subdivision, style terminal, stigmatic branches 4, stigma clavate to capitate; nectar disc usually present at ovary base. Fruits drupaceous with 4 locules, each 1-seeded, occasionally 3 locules aborting and drupes asymmetric, or fruits ellipsoid and fibrous-walled and dispersed with the marcescent corolla, generally with a slightly to greatly accrescent calyx.

Two genera (Cordia and Varronia P.Browne; see Appendix 2) with ca. 400 species of worldwide distribution, especially in the tropics and subtropics. The subfamilial classification of Cordiaceae has long been debated. Ivan Johnston in numerous publications of his series "Studies in the Boraginaceae" (Johnston, 1930, 1935, 1949, 1950, 1951) recognized a broadly defined Cordia with 5-7 sections (see also Hilger \& Zippel, 2001). Recent molecular studies indicate that Varronia is sister to the rest of Cordia, and Miller \& Gottschling (2007) argued for its recognition as a distinct genus. Cordiaceae is the only family in Boraginales with plicate cotyledons and generally a twice-dichotomous style with four stigmatic branches. Cordiaceae have been recognized as a family or as part of the Heliotropiaceae or Boraginaceae (see Appendix 1).

Ehretiaceae Mart., Nov. Gen. Sp. Pl. 2: 136, 138. 1827, nom. cons. - Type: Ehretia P.Browne.

= Ehretieae Dumort., Anal. Fam. Pl.: 25. 1829.

$=$ Ehretioideae Arn., Botany [preprint from Encycl. Brit., ed. 7, 5]: 122.1832 ("Ehretieae").

Trees, shrubs, perennial herbs, rarely with thorns (Rochefortia), indumentum variable, hirsute to glabrescent. Leaves alternate, entire, petiolate, lamina variable in shape, strongly dissected in the halophytic Cortesia Cav. Inflorescences terminal or axillary, thyrsoidal, sometimes congested. Flowers pentamerous, bisexual or unisexual and dioecious in Lepidocordia Ducke and Rochefortia; calyx lobes united in a tube or distinct nearly to the base, tubular to campanulate, aestivation imbricate (mostly quincuncial); corolla white, red or blue (Halgania Gaudich., some Bourreria P.Browne), sympetalous, generally tubular with spreading lobes, rotate, or campanulate to urceolate, aestivation imbricate; stamens 5, the filaments generally adnate to the corolla tube at least at the base, sometimes puberulent at the point of insertion, anthers usually exerted; gynoecium bicarpellate, ovary one to tetralocular from secondary subdivision, style terminal, stigmatic branches (1)2, stigma clavate to capitate; nectar disc usually present at ovary base. Fruits generally drupaceous, often drying and separating into two two-seeded pyrenes, or 41 -seeded pyrenes or schizocarps, or 4 nutlets.

Seven genera (Appendix 2) with ca. 150 species of worldwide distribution, especially in the tropics and subtropics. Generic delimitation and relationships in the Ehretiaceae are reasonably well understood as a consequence of recent molecular studies (Gottschling \& al., 2014a; Weigend \& al., 2014), but it is not clear at present whether they include Lennoaceae, or are the sister group of this parasitic family. Ehretiaceae are morphologically heterogeneous and diverse, and the only trait known at present holding them together are their bifid styles with two stigmatic branches (putatively a plesiomorphic character). Ehretiaceae have been variously included in Boraginaceae, Cordiaceae, Heliotropiaceae, or defined in a strict sense as a family of their own (see Appendix 1).

Heliotropiaceae Schrad. in Commentat. Soc. Regiae Sci. Gott. Recent. 4: 192. 1819, nom. cons. - Type: Heliotropium L. = Heliotropieae Dumort., Fl. Belg.: 39. 1827.

= Tournefortieae Bartl., Ord. Nat. P1.: 197. 1830 ("Tournefortiea").

= Heliotropioideae Arn., Botany [preprint from Encycl. Brit., ed. 7, 5]: 122. 1832 ("Heliotropieae").

Annual or perennial herbs, subshrubs, shrubs, lianas or small trees, indumentum pubescent, often strigose, sericeous or glandular. Leaves alternate, usually entire, very rarely crenate or dentate, often revolute, petiolate or sessile, lamina linear to suborbicular. Inflorescences terminal or axillary, thyrsoids, partial inflorescences scorpioid cymes. Flowers pentamerous, bisexual, rarely unisexual; calyx mostly divided nearly to base, lobes linear to ovate, usually pubescent, tube usually short, mostly campanulate, aestivation valvate; corolla white, yellow, blue, pink or orange, sympetalous, with subcircular to linear lobes, aestivation (sub-)valvate, apert-duplicative, imbricate (quincuncial or cochlear); stamens 5, filaments adnate to the corolla tube, anthers usually included; gynoecium bicarpellate, ovary usually 4-locular, style terminal with a conical stigmatic head having a basal ring-shaped stigma and a sterile, sometimes 2-lobed apex; nectar disc present at ovary base. Fruit dry or fleshy, usually 4-seeded, rarely 1-2-seeded, sometimes with sterile chambers, separating into 1-4 nutlets with 1-2 seeds each.

Four genera (Appendix 2) with ca. 450 species of worldwide distribution, especially in the tropics and subtropics. The family comprises the type genus Heliotropium (incl. Tournefortia L.) and the genera Euploca Nutt., Ixorhea Fenzl (monospecific) and Myriopus Small. Ixorhea is sister to Euploca and Myriopus (Weigend \& al., 2014). Together they form a clade sister to Heliotropium, which comprises four major clades: Heliotropium sect. Heliothamnus I.M.Johnst., Old World Heliotropium, Heliotropium sect. Cochranea (Miers) Post $\&$ Kuntze, and the Tournefortia-clade, the latter comprising Tournefortia sect. Tournefortia and all remaining New World species of Heliotropium (Hilger \& Diane, 2003; Luebert \& al., 2011b). Heliotropiaceae vary from herbs to vines, shrubs, and trees, mostly with distinctly scorpioid cymose inflorescences, but are unique in the possession of conical stigmatic heads, which is a synapormorphy for this family. Heliotropiaceae also have been recognized as a subfamily of Boraginaceae, included in Ehretieae in its entirety, or split into Heliotropioideae and Ehretioideae (see Appendix 1).

Hoplestigmataceae Gilg in Engler \& Gilg, Syllabus, ed. 9 \& 10: 322. 1924, nom. cons. - Type: Hoplestigma Pierre. $=$ Hoplestigmateae Reveal in Phytoneuron 2012-33: 2. 2012. 
Trees, indumentum pubescent to glabrescent. Leaves alternate, entire, petiolate, obovate, abaxially hirsute. Inflorescences terminal thyrsoids, with dichasial paracladia. Flowers 10-15-merous, bisexual, borne in cymes with subscorpioid branches; calyx torn into uneven lobes, united in a tube, lobes ovate, densely villous, irregularly rupturing at anthesis; corolla white, sympetalous, with 11-14 deeply divided lobes, aestivation imbricate; stamens 20-30 in three irregular series, free from corolla, anthers included; gynoecium bicarpellate, ovary unilocular with four pendulous anatropous ovules, style terminal, stigmatic branches 2, stigma capitate; nectar disc possibly present at ovary base. Fruits drupaceous included in a slightly accrescent calyx, endocarp undivided, with four seeds and two additional sterile chambers.

A single genus (Hoplestigma) and two species endemic to central and western Africa. Hoplestigma is unique in having polymerous flowers and very large drupaceous fruits with large sterile chambers. Hoplestigma was first placed in Flacourtiaceae (Pierre, 1899), and later placed, with some uncertainty, in Ebenales (Gilg, 1908; Wagenitz, 1964), Bixales (Hutchinson, 1959), Violales, and in Boraginales (see Appendix 1).

Hydrophyllaceae R.Br. in Bot. Reg. 3: ad t. 242. 1817, excl. gen., nom. cons. - Type: Hydrophyllum L.

$=$ Hydrophyllineae Link, Handbuch 1: 570. 1829.

= Romanzoffieae Dumort., Anal. Fam. Pl.: 26. 1829 ("Romanzoviaceae").

= Hydrophylleae Rchb., Fl. Germ. Excurs.: 347. 1831.

= Hydrophylloideae Burnett, Outlines Bot.: 1006, 1095, 1105. 1835 ("Hydrophyllidae").

= Ellisieae Rchb., Handb. Nat. Pfl.-Syst.: 193. 1837.

= Nemophileae Rchb., Handb. Nat. Pfl.-Syst.: 193. 1837.

= Eutocaceae Horan., Char. Ess. Fam.: 124. 1847.

$=$ Phacelieae Benth. ex A.Gray in Proc. Amer. Acad. Arts 10: 312. 1875.

= Hydrophyllinae Reveal in Phytoneuron 2012-33: 2. 2012.

$=$ Phaceliinae Reveal in Phytoneuron 2012-37: 218. 2012.

= Romanzoffiinae Reveal in Phytoneuron 2012-37: 218. 2012.

Annual, biennial, or perennial herbs, indumentum usually scabrid to hispid, often glandular. Leaves cauline and basal, rarely basal or cauline only, alternate, undivided or-more commonly — variously divided to bipinnate. Inflorescences terminal or axillary, thyrsoidal, usually of scorpioid monochasia, sometimes congested. Flowers (4)5-merous, bisexual; calyx lobes united at base or nearly to apex, linear to cordate, aestivation valvate; corolla commonly blue to purple, but also white, pink or yellow, sympetalous, corolla scales present, small or absent, aestivation contorted or imbricate; stamens 5 of equal or unequal length, filaments equally or unequally adnate to the corolla tube, anthers usually included; gynoecium bicarpellate, ovary unilocular or bilocular, sometimes the two large, fleshy parietal placentae filling the locule at anthesis, ovary thus appearing 2- or 5-celled, or placentae narrow, cartilaginous, partially or completely dividing ovary, style 1 , terminal, stigmatic branches 2, stigma capitate; nectar disc present or reduced to glands at ovary base. Fruit a membranaceous capsule appearing 2-celled, dehiscence loculicidal with 2 valves, 1-many-seeded.
Twelve genera (Appendix 2) with about 240-260 species restricted to North and Central America and western South America. The family comprises the type genus Hydrophyllum and Draperia Torr., Ellisia L., Emmenanthe Benth., Eucrypta Nutt., Hesperochiron S.Watson, Howellanthus (Constance) Walden \& R.Patt., Nemophila Nutt., Phacelia Juss., Pholistoma Lilja, Romanzoffia Cham., and Tricardia Torr. The circumscription of Hydrophyllaceae is here amended, excluding the entire tribe Nameae, traditionally considered part of this family. Hydrophyllaceae has three major clades (Ferguson, 1999; Walden, 2010), a clade of Phacelia+Romanzoffia (equivalent to Romanzoffieae; Walden \& al., 2014), a clade of Hydrophyllum + Pholistoma + Nemophila +Emmenanthe + Ellisia + Eucrypta (equivalent to Hydrophylleae; Walden, 2015), and a clade (otherwise unnamed) of Draperia + Tricardia + Howellanthus + Hesperochiron (Walden, unpub. data). Gray (1875) defined Hydrophyllaceae to include Hydrophylleae, Phacelieae, Namaeae, and Hydroleae in Hydrophyllaceae, a delimitation followed by most modern authors, but Hydrophyllaceae have also been regarded as a member of Boraginaceae (see Appendix 1).

Lennoaceae Solms in Abh. Naturf. Ges. Halle 11: 174. 1870, nom. cons. - Type: Lennoa Lex.

= Pholismateae Horan., Char. Ess. Fam.: 109. 1847 ("Pholisma").

$=$ Lennooideae Torr. in Ann. Lyceum Nat. Hist. New York 8: 56. 1854 ("Lennoeae").

= Lennoeae Baill., Hist. Pl. (Baillon) 11: 161, 207. 1891.

Parasitic herbs, without chlorophyll, indumentum shortly pubescent, often glandular. Leaves reduced to cataphylls. Inflorescences terminal, densely spicate or capitate cymosethyrsoids. Flowers (4)5-9(10)-merous, bisexual; calyx tubular or divided nearly to base, 6-10-lobed, the lobes narrow, puberulent to tomentose, with glandular trichomes, aestivation valvate; corolla lilac to bluish purple, rarely pink or mauve, sympetalaous, tubular with 5-10 lobes, aestivation imbricate; stamens the same number as the corolla lobes, filaments adnate to the corolla tube, the free portion very short, anthers included; gynoecium 5-16-carpellate, ovary 10-32-locular, style terminal, simple and undivided, stigma capitate; nectar disc absent. Fruits capsular, irregularly circumscissile, releasing 10-32 pyrenes.

Two genera (Lennoa, Pholisma Nutt. ex Hook.) and four species of achlorophyllous root holoparasites distributed in southwestern North America, Mexico, and northwestern South America. The family is distinct in its parasitic habit and 10-32-locular gynoecium. Its fruits are highly unusual, with circumscissile dehiscence and the seeds enclosed in hardened tissue and released as pyrenes. Lennoaceae have been associated with Primulaceae (La Llave \& Lexarza, 1824), Orobanchaceae (Hooker, 1844), Ericales (Bentham \& Hooker, 1876; Engler, 1898), Cuscutaceae (Conzatti \& Smith, 1909), or Boraginineae, or have been treated either as a subfamily in Boraginaceae, or a family of Boraginales (see Appendix 1).

Namaceae Molinari in Weberbauerella 1(7): 2. 2016 - Type: Nama L.

$=$ Nameae Choisy in Candolle, Prodr. 10: 182. 1846.

= Namoideae A.W.Benn. in J. Linn. Soc., Bot. 11: 266. 1870. 
= Wigandieae Horan., Char. Ess. Fam.: 124. 1847. ("Wigandieae [Hydroleaceae]").

Shrubs or small, soft-wooded trees, or herbaceous (only Nama), erect, or decumbent, with well-developed tap-root, rarely rhizomatous (only Eriodictyon), usually densely pubescent with uni-cellular and pluricellular, glandular trichomes, sometimes with stinging hairs and/or resinous, rarely tomentose or glabrate. Leaves cauline only, alternate, simple, subsessile to distinctly long-petiolate, margin entire to coarsely serrate or lobed, usually densely pubescent. Inflorescences terminal or axillary, thyrsoidal, usually of boragoids (see Glossary), sometimes congested, bracteose or frondose. Flowers pentamerous, bisexual; calyx lobes united at base or nearly to apex, aestivation valvate; corolla white to purple or lavender, sympetalous, tubular, infundibuliform to campanulate, usually pubescent, aestivation imbricate; stamens 5, equal or unequal in length, equally or unequally adnate to the corolla tube, staminal appendages present or absent sometimes only filament bases dilated, anthers included; gynoecium bicarpellate, ovary bilocular, placentae narrow, membranaceous or cartilaginous, completely dividing ovary, style terminal, stylodia 2 , distinct to base or connate $3 / 4$ of length (= stylar branches, only Nama sect. Conanthus), stigma bilobate; nectar disc present at ovary base. Fruit a capsule appearing 2-celled, dehiscing loculicidally or loculicidally and septicidally, with 2 or 4 valves, respectively, 2-many-seeded.

Four genera (Eriodictyon Benth., Nama, Turricula J.F. Macbr., Wigandia Kunth) with a total of ca. 75 species in the Americas and the Caribbean, and one species in Hawaii.

Namaceae has two major clades, the first clade comprising Nama, and a second clade comprising Wigandia, Eriodictyon, and Turricula (Ferguson, 1999; Taylor, 2012). Two species of Nama are in the second clade, N. rothrockii A.Gray and $N$. lobbii A.Gray, which are successive sisters to Turricula (Walden, unpub. data). Nama was first included in Hydroleaceae along with Hydrolea (Brown, 1818). Hydroleaceae was later transferred to Hydrophyllaceae (Bentham \& Hooker, 1976) and retained there until recently (e.g., Davenport, 1988). Based on phylogenetic studies (Cosner \& al., 1994; Soltis \& al., 2000), Hydrolea was excluded from Hydrophyllaceae and placed as a monogeneric family in Solanales (see Appendix 1).

Wellstediaceae Novák in Prát, Rostlinopis 9: 530. 1943 - Type: Wellstedia Balf.f.

= Wellstedioideae Pilg. in Bot. Jahrb. Syst. 46: 558. 1912.

Small densely branched herbs or shrublets, indumentum sericeous, acroscopically appressed. Leaves cauline, sometimes some basal, often alternate and distichous on branches, simple, sessile or petiolate, oblanceolate, ovate or obovate. Inflorescences axillary cymes or reduced to single flowers. Flowers tetramerous, bisexual; calyx deeply divided, lobes linear-lanceolate, abaxially pubescent, aestivation valvate; corolla pink to white or yellowish, sympetalous, deeply divided into four lobes, tube inside with 4 protrusions often fused into a distinct rim, aestivation imbricate; stamens 4, filaments free, anthers included; gynoecium bicarpellate, ovary bilocular, style terminal with two short stigmatic lobes, stigma bilobate; nectar disc absent. Fruit a bivalved capsule; seeds one, rarely two, asymmetrically ovoid in lateral view, strongly laterally compressed, pubescent, often with ring of longer hairs near funicular pole.

One genus (Wellstedia) and six species disjunctly distributed in arid zones of southwestern and northeastern Africa and Socotra (Thulin \& Johansson, 1996; Thulin, 1998). Wellstedia is easily recognized by its 4-merous flowers, and unusual flattened, obcordate capsular fruits. Wellstedia was first considered a subfamily of Boraginaceae and treated as such by most authors, although some authors have also regarded it as an independent family (see Appendix 1).

\section{GLOSSARY}

Anthoclade: Frondose inflorescences with extended growth and elongating internodes, resembling vegetative branches of the plant.

Boragoid: A modified cincinnus with the consecutive branches aligned more or less in the direction of the main axis causing the flowers to be pushed aside and appearing like solitary axillary flowers borne on a main axis (Buys \& Hilger, 2003).

Drupe: A fruit where the - usually single — seed is enclosed in a hardened (sclerenchymatic or lignescent) inner layer of the fruit wall (endocarp), whereas the outer layers of the fruit wall (ovary wall in Boraginales) are parenchymatic, often soft and succulent, sometimes spongiose or fibrous.

Endocarp: The inner, sometimes undifferentiated, sometimes hardened (sclerenchymatic or lignescent) layers of the fruit wall enclosing the seed or seeds.

Eremocarp: A nutlet going back to part of the (united) ovary via ab initio separate development, i.e., not arising via secondary subdivision during fruit development (= schizocarp). It consists of one, very rarely two seeds enclosed by a dry pericarp and showing a basal or adaxial abscission line (forming a closed-line figure: circular, elliptical, triangular). Part of the ovary, called replum or gynobase, remains attached to the mother plant (Hilger, 2014).

Pyrene: Descriptive term for the (central) part of a fruit comprising a hardened (sclerenchymatic or lignescent) endocarp and the seed(s) enclosed. Usually a single one per fruit, rarely several seeds are separately enclosed in endocarps (e.g., Lennoaceae). The pyrene wall is ruptured during germination to release the seedling.

Schizocarp: A fruit separating completely into individually dispersed seed-bearing units, typically comprising part of the fruit wall and seeds (mericarps).

\section{ACKNOWLEDGEMENTS}

We thank Hans Jürgen Ensikat for SEM pictures, Juliana Chacón, Norbert Holstein, and Julius Jeiter for discussion. We are grateful to the Editor, Hervé Sauquet, and two anonymous reviewers for constructive criticism on an earlier version of this manuscript. 


\section{LITERATURE CITED}

Acevedo-Rodríguez, P. \& Strong, M.T. 2012. Catalogue of seed plants of the West Indies. Washington, D.C.: Smithsonian Institution Scholarly Press.

Al-Shehbaz, I.A. 1991. The genera of Boraginaceae in the southeastern United States. J. Arnold Arbor. 1: 1-169.

APG (Angiosperm Phylogeny Group) 1998. An ordinal classification for the families of flowering plants. Ann. Missouri Bot. Gard. 85: 531-553. http://dx.doi.org/10.2307/29920Г5

APG II 2003. An update of the Angiosperm Phylogeny Group classification for the orders and families of flowering plants: APG II. Bot. J. Linn. Soc. 141: 399-436. http://dx.doi.org/10.1046/j.1095-8339.2003.t01-1-00158.x

APG III 2009. An update of the Angiosperm Phylogeny Group classification for the orders and families of flowering plants: APG III. Bot. J. Linn. Soc. 161: 105-121. http://dx.doi.org/10.1111/j.1095-8339.2009.00996.x

Aubréville, A. 1959. La flore forestière de la Côte d'Tvoire, ed. 2. Nogent-sur-Marne: Centre Technique Forestier Tropical.

Backlund, A. \& Bremer, K. 1998. To be or not to be: Principles of classification and monotypic plant families. Taxon 47: 391-400. http://dx.doi.org/10.2307/1223768

Baillon, H.E. 1891. Histoire des plantes, vol. 10. Paris: Librairie Hachette. http://dx.doi.org/10.5962/bhl.title.40796

Bentham, G. \& Hooker, J.D. 1876. Genera plantarum, vol. 2(2). Londini [London]: Reeve, etc. http://dx.doi.org/10.5962/bhl.title.747

Berchtold, F. \& Presl, J.S. 1820. O prirozenosti Rostlin. Praha: Krala Wiljma Endersa.

Brand, A. 1913. Hydrophyllaceae. In: Engler, A. (ed.), Das Pflanzenreich, IV.251 (Heft 59). Leipzig: Engelmann.

Bremer, B., Bremer, K., Heidari, N., Erixon, P., Olmstead, R.G., Anderberg, A.A., Källersjö, M. \& Barkhordarian, E. 2002. Phylogenetics of asterids based on 3 coding and 3 non-coding chloroplast DNA markers and the utility of non-coding DNA at higher taxonomic levels. Molec. Phylogen. Evol. 24: 274-301. http://dx.doi.org/10.1016/S1055-7903(02)00240-3

Brown, R. 1818. Observations systematical and geographical on the herbarium collected by Professor Christian Smith, in the vicinity of the Congo. London: printed by W. Bulmer. https://books.google.at/books?id=7HkQAQAAMAAJ

Buys, M.H. \& Hilger, H.H. 2003. Boraginaceae cymes are exclusively scorpioid and not helicoid. Taxon 52: 719-724. http://dx.doi.org/10.2307/3647346

Campos-Ríos, M.G. \& Chiang-Cabrera, F. 2012. El género Varronia P. Browne (Cordiaceae, Boraginales) en México. Polibotanica 33: 1-32.

Candolle, A. de 1845. Prodromus systematis naturalis regni vegetabilis, vol. 9. Parisiis [Paris]: sumptibus Fortin etc. http://dx.doi.org/10.5962/bhl.title.286

Candolle, A. de 1846. Prodromus systematis naturalis regni vegetabilis, vol. 10. Parisiis [Paris]: sumptibus Victoris Masson. http://dx.doi.org/10.5962/bhl.title.286

Candolle, A. de 1873. Prodromus systematis naturalis regni vegetabilis, vol. 17. Parisiis [Paris]: sumptibus G. Masson. http://dx.doi.org/10.5962/bhl.title.286

Cecchi, L. \& Selvi, F. 2015a. Flora critica d'Italia: Hydrophyllaceae, version 1.0. Florence: Fondazione per la Flora Italiana. http://www.floraditalia.it/

Cecchi, L. \& Selvi, F. 2015b. Flora critica d'Italia: Heliotropiaceae, version 1.0. Florence: Fondazione per la Flora Italiana. http://www.floraditalia.it/

Chadefaud, M. \& Emberger, L. 1960. Traité de botanique systématique. Paris: Masson.

Cohen, J.I. 2014. A phylogenetic analysis of morphological and molecular characters of Boraginaceae: Evolutionary relationships, taxonomy, and patterns of character evolution. Cladistics 30: 139-169. http://dx.doi.org/10.1111/cla.12036
Constance, L. 1963. Chromosome number and classification in Hydrophyllaceae. Brittonia 15: 273-285. http://dx.doi.org/10.2307/2805376

Conzatti, C. \& Smith, L.C. 1909. Flora sinóptica mexicana, ed. 2, vol. 2. Mexico: Imprenta y fototipia de la secretaria de fomento.

Cosner, M.E., Jansen, R.K. \& Lammers, T.G. 1994. Phylogenetic relationships in the Campanulales based on $r b c L$ sequences. $P l$. Syst. Evol. 190: 79-95. http://dx.doi.org/10.1007/BF00937860

Cronquist, A. 1981. An integrated system of classification of flowering plants. New York: Columbia University Press.

Cronquist, A. 1988. The evolution and classification of flowering plants. New York: New York Botanical Garden.

Dahlgren, R.M. T. 1980. A revised system of classification of the angiosperms. Bot. J. Linn. Soc. 80: 91-124. http://dx.doi.org/10.1111/j.1095-8339.1980.tb01661.x

Davenport, L.J. 1988. A monograph of Hydrolea (Hydrophyllaceae). Rhodora 90: 169-208.

Davidse, G., Sousa Sánchez, M., Knapp, S. \& Chiang Cabrera, F. (eds.) 2012. Flora Mesoamericana, vol. 4(2). St. Louis: Missouri Botanical Garden Press.

Diane, N., Hilger, H.H. \& Gottschling, M. 2002. Transfer cells in the seeds of Boraginales. Bot. J. Linn. Soc. 140: 155-164. http://dx.doi.org/10.1046/.1095-8339.2002.00085.x

Di Fulvio, T.E. 1978. Sobre la vasculatura floral, embriología y chromosomas de Ixorhea tschudiana (Heliotropiaceae). Kurtziana 11: $75-105$.

Dumortier, B.-C. 1829. Analyse des familles des plantes. Tournay: imprimerie de J. Casterman. http://dx.doi.org/10.5962/bhl.title.443

Endlicher, S. 1836-1840. Genera plantarum secundum ordines naturales disposita. Vindobonae [Vienna]: apud Fr. Beck. http://dx.doi.org/10.5962/bhl.title.728

Engler, A. (ed.) 1893. Die natürlichen Pflanzenfamilien, IV(3a). Leipzig: Engelmann. http://dx.doi.org/10.5962/bhl.title.4635

Engler, A. 1898. Syllabus der Pflanzenfamilien, ed. 2. Berlin: Gebrüder Borntraeger. https://archive.org/details/syllabusderpfla00englgoog

Engler, A. (ed.) 1908. Die natürlichen Pflanzenfamilien, Ergänzungsh. 2. Leipzig: Engelmann. http://dx.doi.org/10.5962/bhl.title.4635

Engler, A. (ed.) 1915. Die natürlichen Pflanzenfamilien, Ergänzungsh. 3. Leipzig: Engelmann. http://dx.doi.org/10.5962/bhl.title.4635

Ferguson, D.M. 1999. Phylogenetic analysis and relationships in Hydrophyllaceae based on $n d h F$ sequence data. Syst. Bot. 23: 253-268. http://dx.doi.org/10.2307/2419504

Gasparino, E.C. \& Vitorino da Cruz Barros, M.A. 2009. Palinotaxonomia das espécies de Cordiaceae (Boraginales) ocorrentes no Estado de São Paulo. Revista Brasil. Bot. 32: 33-55. http://dx.doi.org/10.1590/s0100-84042009000100005

Gilg, E. 1908. Die systematische Stellung der Gattung Hoplestigma und einiger anderer zweifelhafter Gattungen. Bot. Jahrb. Syst. 40: 76-84.

Gottschling, M., Hilger, H.H., Wolf, M. \& Diane, N. 2001. Secondary structure of the ITS1 transcript and its application in a reconstruction of the phylogeny of Boraginales. Pl. Biol. (Stuttgart) 3: 629-636. http://dx.doi.org/10.1055/s-2001-19371

Gottschling, M., Miller, J.S., Weigend, M. \& Hilger, H.H. 2005. Congruence of a phylogeny of Cordiaceae (Boraginales) inferred from ITS1 sequence data with morphology, ecology, and biogeography. Ann. Missouri Bot. Gard. 92: 425-437.

Gottschling, M., Luebert, F., Hilger, H.H. \& Miller, J.S. 2014a. Molecular delimitations in the Ehretiaceae (Boraginales). Molec. Phylogen. Evol. 72: 1-6. http://dx.doi.org/10.1016/j.ympev.2013.12.005

Gottschling, M., Nagelmüller, S. \& Hilger, H.H. 2014b. Generative ontogeny in Tiquilia (Ehretiaceae: Boraginales) and phylogenetic implications. Biol. J. Linn. Soc. 112: 520-534. http://dx.doi.org/10.1111/bij.12266

Gray, A. 1862. Characters of new or obscure species of plants of monopetalous orders in the collection of the United States South 
Pacific Exploring Expedition under Captain Charles Wilkes, U. S. N. with occasional remarks \&c. Proc. Amer. Acad. Arts Sci. 5: 321-352.

Gray, A. 1875. A conspectus of the North American Hydrophyllaceæ. Proc. Amer. Acad. Arts Sci. 10: 312-332. http://dx.doi.org/10.2307/20021420

Gürke, M. 1893. Borraginaceae (Asperifoliaceae). Pp. 71-131 in: Engler, A. (ed.), Die natürlichen Pflanzenfamilien, vol. IV(3a). Leipzig: Engelmann. http://dx.doi.org/10.5962/bhl.title.4635

Hepper, F.N. 1963. Hoplestigmataceae. Pp. 15-16 in: Hepper, F.N. (eds.), Flora of west tropical Africa, vol. 2. London: Crown Agents for Oversea Governments and Administrations.

Heywood, V.H. 2007. Flowering plant families of the world. Kew: Royal Botanic Gardens.

Hilger, H.H. 1985. Ontogenie, Morphologie und systematische Bedeutung geflügelter und glochidientragender Cynoglosseae- und Eritrichieae-Früchte (Boraginaceae). Bot. Jahrb. Syst. 105: 323-378.

Hilger, H.H. 1987. Flower and fruit development in Wigandia caracasana (Hydrophyllaceae). Amer. J. Bot. 74: 250-259. http://dx.doi.org/10.2307/2444027

Hilger, H.H. 2014. Ontogeny, morphology, and systematic significance of glochidiate and winged fruits of Cynoglosseae and Eritrichieae (Boraginaceae). Pl. Diversity Evol. 131: 167-214. http://dx.doi.org/10.1127/1869-6155/2014/0131-0080

Hilger, H.H. \& Diane, N. 2003. A systematic analysis of Heliotropiaceae (Boraginales) based on trnL and ITS1 sequence data. Bot. Jahrb. Syst. 125: 19-51. http://dx.doi.org/10.1127/0006-8152/2003/0125-0019

Hilger, H.H. \& Zippel, E. 2001. "Studies in the Boraginaceae": An index to the publications of Ivan M. Johnston dealing with the Borage family. Haussknechtia Beiheft 11: 1-151.

Hilger, H.H., Gottschling, M., Selvi, F., Bigazzi, M., Långström, E., Zippel, E., Diane, N. \& Weigend, M. 2005. The Euro+Med treatment of Boraginaceae in Willdenowia 34 - A response. Willdenowia 35: 43-48. http://dx.doi.org/10.3372/wi.35.35101

Hofmann, M. 1999. Flower and fruit development in the genus Phacelia (Phacelieae, Hydrophyllaceae): Characters of systematic value. Syst. \& Geogr. Pl. 68: 203-212. http://dx.doi.org/10.2307/3668601

Hofmann, M. 2004. Hydrophyllaceae. Pp. 190-191 in: Smith, N., Mori, S.A., Henderson, A., Stevenson. D.W. \& Heald, S.V. (eds.), Flowering plants of the Neotropics. Princeton: Princeton University Press.

Hooker, W.J. 1844. Icones plantarum, vol. 7 [n.s. vol. 3]. London: Hippolyte Baillière. http://dx.doi.org/10.5962/bhl.title.16059

Howard, R.A. 1989. Boraginaceae. Pp. 188-211 in: Howard, R.A. (ed.), Flora of the Lesser Antilles, vol. 6. Jamaica Plain, Massachusetts: Arnold Arboretum, Harvard University.

Hutchinson, J. 1959. The families of flowering plants: Dicotyledons. Oxford: Clarendon Press.

Irimia, R.-E., Pérez-Escobar, O.A. \& Gottschling, M. 2015. Strong biogeographic signal in the phylogenetic relationships of Rochefortia Sw. (Ehretiaceae, Boraginales). Pl. Syst. Evol. 301: 1509-1516. http://dx.doi.org/10.1007/s00606-014-П62-1

Johnston, I.M. 1924. A tentative classification of the South American Coldenias. Contr. Gray Herb. 70: 55-61.

Johnston, I.M. 1930. Studies in the Boraginaceae VIII. I. Observations on the species of Cordia and Tournefortia known from Brazil. Contr. Gray Herb. 92: 3-89.

Johnston, I.M. 1935. Studies in Boraginaceae X. The Boraginaceae of northeastern South America. J. Arnold Arbor. 16: 1-64.

Johnston, I.M. 1949. Studies in the Boraginaceae XVII. A. Cordia section Varronia in Mexico and Central America. J. Arnold Arbor. 30: 85-104. http://dx.doi.org/10.5962/bhl.part.18047

Johnston, I.M. 1950. Studies in the Boraginaceae XIX. B. Cordia $\S$ Gerascanthus in Mexico and Central America. J. Arnold Arbor. 31: $179-187$.

Johnston, I.M. 1951. Studies in the Boraginaceae XX. Representatives of three subfamilies in eastern Asia. J. Arnold Arbor. 32: 1-26, 99-122. http://dx.doi.org/10.5962/bhl.part.9727
Judd, W.S., Campbell, S., Kellogg, E.A., Stevens, P.F. \& Donoghue, M.J. 2008. Plant systematics: A phylogenetic approach, ed. 3. Sunderland, Massachusetts: Sinauer.

Jussieu, A.L. de 1789. Genera plantarum secundum ordines naturales disposita. Parisiis [Paris]: apud viduam Herissant, etc. http://dx.doi.org/10.5962/bhl.title.7762

Kadereit, J.W., Körner, C., Kost, B. \& Sonnewald, U. 2014. Strasburger: Lehrbuch der Pflanzenwissenschaften. Berlin, etc.: Springer. http://dx.doi.org/10.1007/978-3-642-54435-4

Kadereit, J.W. \& Bittrich, V. (eds.) 2016. The families and genera of vascular plants, vol. 14, Flowering plants: Eudicots; Aquifoliales, Boraginales, Bruniales, Dipsacales, Escalloniales, Garryales, Paracryphiales, Solanales (except Convolvulaceae), Icacinaceae, Metteniusaceae, Vahliaceae. Cham: Springer International Publishing. http://dx.doi.org/10.1007/978-3-319-28534-4

La Llave, P. \& Lexarza, J.J.M. 1824. Novorum vegetabilium descriptiones, vol. 1. Méxici [Mexico]: apud Martinum Riveram. http://bibdigital.rjb.csic.es/ing/Libro.php?Libro=7019

Lindley, J. 1831. An introduction to the natural system of botany. New York: G. \& C. \& H. Carvill. http://dx.doi.org/10.5962/bhl.title.7554

Liogier, H.A. 1994. La flora de la Española. San Juan: Editorial de la Universidad de Puerto Rico.

Liu, B.,Ye, J., Liu, S., Wang, Y., Yang, Y., Lai, Y., Zeng, G. \& Lin, Q. 2015. Families and genera of Chinese angiosperms: A synoptic classification based on APG III (in Chinese). Biodivers. Sci. 23: 225-231. http://dx.doi.org/10.17520/biods.2015052

Luebert, F. 2013. A revision of Heliotropium sect. Cochranea (Heliotropiaceae). Kew Bull. 68: 1-54. http://dx.doi.org/10.1007/s12225-013-9432-6

Luebert, F. \& Hilger, H.H. 2014. Typification of Heliotropium and Tournefortia (Heliotropiaceae) species described by Ruiz and Pavón. Anales J. Bot. Madrid 71: e012. http://dx.doi.org/10.3989/ajbm.2332

Luebert, F. \& Wen, J. 2008. Phylogenetic analysis and evolutionary diversification of Heliotropium sect. Cochranea (Heliotropiaceae) in the Atacama Desert. Syst. Bot. 33: 390-402. http://dx.doi.org/10.1600/036364408784571635

Luebert, F., Weigend, M. \& Hilger, H.H. 2010. Epitypification of Heliotropium arborescens L. (Heliotropiaceae). Taxon 59: $1263-1266$

Luebert, F., Hilger, H.H. \& Weigend, M. 2011a. Diversification in the Andes: Age and origins of South American Heliotropium lineages (Heliotropiaceae, Boraginales). Molec. Phylogen. Evol. 61: 90-102. http://dx.doi.org/10.1016/j.ympev.2011.06.001

Luebert, F., Brokamp, G., Wen, J., Weigend, M. \& Hilger, H.H. 2011b. Phylogenetic relationships and morphological diversity in Neotropical Heliotropium (Heliotropiaceae). Taxon 60: 663-680.

Mabberley, D.J. 2008. Mabberley's plant book: A portable dictionary of plants, their classification and uses, ed. 3. Cambridge: Cambridge University Press.

Melchior, H. 1964a. Hydrophyllaceae. Pp. 430-431 in: Melchior, H. (ed.), A. Engler's Syllabus der Pflanzenfamilien, vol. 2. Berlin: Gebrüder Borntraeger.

Melchior, H. 1964b. Boraginaceae. Pp. 431-434 in: Melchior, H. (ed.), A. Engler's Syllabus der Pflanzenfamilien, vol. 2. Berlin: Gebrüder Borntraeger.

Melchior, H. 1964c. Lennoaceae. Pp. 434-434 in: Melchior, H. (ed.), A. Engler's Syllabus der Pflanzenfamilien, vol. 2. Berlin: Gebrüder Borntraeger.

Melo, J.I.M. de \& Semir, J. 2010. Taxonomia do gênero Euploca Nutt. (Heliotropiaceae) no Brasil. Acta Bot. Brasil. 24: 111-132. http://dx.doi.org/10.1590/S0102-33062010000100012

Melo, J.I.M. de, Alves, M. \& Semir, J. 2009. Padrões de distribuição geográfica das espécies de Euploca e Heliotropium (Heliotropiaceae) no Brasil. Rodriguésia 60: 1025-1036.

Merxmüller, H. 1960. Wellstediaceae. Mitt. Bot. Staatssamml. München 3: 619-622. 
Miller, J.S. 2012. New Boraginales from tropical America 7: A new species of Cordia from Bolivia and nomenclatural notes on Neotropical Cordiaceae. Brittonia 64: 359-362. http://dx.doi.org/10.1007/s12228-012-9243-3

Miller, J.S. 2013a. A revision of Cordia section Gerascanthus (Boraginales: Cordiaceae). J. Bot. Res. Inst. Texas 7: 55-83.

Miller, J.S. 2013b. New Boraginales from tropical America 8: Nomenclatural notes on Varronia (Cordiaceae: Boraginales). Brittonia 65: 342-344. http://dx.doi.org/10.1007/s12228-012-9283-8

Miller, J.S. \& Gottschling, M. 2007. Generic classification in the Cordiaceae (Boraginales): Resurrection of the genus Varronia R. Br. Taxon 56: 163-169.

Moore, M.J. \& Jansen, R.K. 2006. Molecular evidence for the age, origin, and evolutionary history of the American desert plant genus Tiquilia (Boraginaceae). Molec. Phylogen. Evol. 39: 668-687. http://dx.doi.org/10.1016/j.ympev.2006.01.020

Moore, M.J., Soltis, P.S., Bell, C.D., Burleigh, J.G. \& Soltis, D.E. 2010. Phylogenetic analysis of 83 plastid genes further resolves the early diversification of Eudicots. Proc. Natl. Acad. Sci. U.S.A. 107: 4623-4628. http://dx.doi.org/10.1073/pnas.0907801107

Nazaire, M. \& Hufford, L. 2012. A broad phylogenetic analysis of Boraginaceae: Implications for the relationships of Mertensia. Syst. Bot. 37: 758-783. http://dx.doi.org/10.1600/036364412X648715

Olmstead, R.G., Bremer, B., Scott, K.M. \& Palmer, J.D. 1993. A parsimony analysis of the Asteridae sensu lato based on $r b c L$ sequences. Ann. Missouri Bot. Gard. 80: 700-722. http://dx.doi.org/10.2307/2399855

Peter, A. 1893. Hydrophyllaceae. Pp. 54-71 in: Engler, A. (ed.), Die natürlichen Pflanzenfamilien, vol. IV(3a). Leipzig: Engelmann. http://dx.doi.org/10.5962/bhl.title.4635

Pierre, L. 1899. Observations sur quelques Bixacées (suite). Bull. Mens. Soc. Linn. Paris 2: 113-119.

Pilger, R. 1912. Die Gattung Wellstedia in Südwestafrika. Bot. Jahrb. Syst. 46: 558-561.

Pilger, R. \& Krause, K. 1915. Die natürlichen Pflanzenfamilien, Ergänzungsh. 3. Leipzig: Engelmann. http://dx.doi.org/10.5962/bhl.title.4635

Refulio-Rodríguez, N.F. \& Olmstead, R.G. 2014. Phylogeny of Lamiidae. Amer. J. Bot. 101: 287-299. http://dx.doi.org/10.3732/ajb.1300394

Retief, E. \& Van Wyk, A.E. 2005. Boraginaceae. Codonoideae, a new subfamily based on Codon. Bothalia 35: 78-80.

Reveal, J.L. 2011. Summary of recent systems of angiosperm classification. Kew Bull. 66: 5-48. http://dx.doi.org/10.1007/ s12225-011-9259-y

Reveal, J.L. 2012. An outline of a classification scheme for extant flowering plants. Phytoneuron 2012: 1-221.

Reveal, J.L. \& Chase, M.W. 2011. APG III: Bibliographical information and synonymy of Magnoliidae. Phytotaxa 19: 71-134. http://dx.doi.org/10.11646/phytotaxa.19.1.4

Richardson, A. 1976. Reinstatement of the genus Tiquilia (Boraginaceae: Ehretioideae) and descriptions of four new species. Sida 6: $235-240$.

Ricketson, J.M. 2012. Hydrophyllaceae. Pp. 291-294 in: Davidse, G., Sousa Sánchez, M., Knapp, S. \& Chiang Cabrera, F. (eds.), Flora Mesoamericana, vol. 4(2). St. Louis: Missouri Botanical Garden Press.

Savolainen, V., Fay, M.F., Albach, D.C., Backlund, A., Van der Bank, M., Cameron, K.M., Johnson, S.A., Lledó, M.D., Pintaud, J.-C., Powell, M., Sheahan, M.C., Soltis, D.E., Soltis, P.S., Weston, P., Whitten, W.M., Wurdack, K.J. \& Chase, M.W. 2000. Phylogeny of the Eudicots: A nearly complete familial analysis based on $r b c L$ gene sequences. Kew Bull. 55: 257-309. http://dx.doi.org/10.2307/4115644

Simpson, M.G. 2010. Plant systematics, ed. 2. Burlington: Academic Press. http://dx.doi.org/10.1016/b978-0-12-374380-0.50001-4

Sklenář, P., Luteyn, J.L., Ulloa Ulloa, C., Jørgensen, P.M. \& Dillon,
M.O. 2005. Flora genérica des los Páramos: Guía ilustrada de las plantas vasculares. Mem. New York Bot. Gard. 92: 1-499.

Soltis, D.E., Soltis, P.S., Chase, M.W., Mort, M.E., Albach, D.C., Zanis, M., Savolainen, V., Hahn, W.H., Hoot, S.B., Fay, M.F., Axtell, M., Swensen, S.M., Prince, L.M., Kress, W.J., Nixon, K.C. \& Farris, J.S. 2000. Angiosperm phylogeny inferred from 18S rDNA, rbcL, and $a t p B$ sequences. Bot. J. Linn. Soc. 133: 381461. http://dx.doi.org/10.1111/j.1095-8339.2000.tb01588.x

Soltis, D.E., Smith, S.A., Cellinese, N., Wurdack, K.J., Tank, D.C., Brockington, S.F., Refulio-Rodriguez, N.F., Walker, J.B., Moore, M.J., Carlsward, B.S., Bell, C.D., Latvis, M., Crawley, S., Black, C., Diouf, D., Xi, Z., Rushworth, C.A., Gitzendanner, M.A., Sytsma, K.J., Qiu, Y.-L., Hilu, K.W., Davis, C.C., Sanderson, M.J., Beaman, R.S., Olmstead, R.G., Judd, W.S., Donoghue, M.J. \& Soltis, P.S. 2011. Angiosperm phylogeny: 17 genes, 640 taxa. Amer. J. Bot. 98: 704-730. http://dx.doi.org/10.3732/ajb.1000404

Stapf, M.N.S. 2009. Neotropical Boraginaceae. In: Milliken, W., Klitgård, B. \& Baracat, A., Neotropikey - Interactive key and information resources for flowering plants of the Neotropics. Kew: Royal Botanic Gardens. http://www.kew.org/science/tropamerica/ neotropikey/families/Boraginaceae.htm (accessed 7 Sep 2015).

Stapf, M.N.S., Ranga, N.T. \& Silva, T.R. S. 2010. A new species of Cordia (Cordiaceae, Boraginales) from Brazil. Novon 20: 212-214. http://dx.doi.org/10.3417/2007099

Stapf, M.N.S. de \& Silva, T. dos S. 2013a. Four new species of genus Cordia (Cordiaceae, Boraginales) from Brazil. Brittonia 65: 191-199. http://dx.doi.org/10.1007/s12228-012-9268-7

Stapf, M.N.S. de \& Silva, T. dos S. 2013b. Typifications in Cordia (Cordiaceae), with an assessment of the status of Cordia blanchetii. Kew Bull. 68: 355-359. http://dx.doi.org/10.1007/s12225-013-9439-z

Stevens, P.F. 2001-. Angiosperm Phylogeny Website, version 9, June 2008 [and more or less continuously updated since]. http://www. mobot.org/mobot/research/apweb/welcome.html (accessed 16 Oct 2015).

Stull, G.W., Duno de Stefano, R.D., Soltis, D.E. \& Soltis, P.S. 2015. Resolving basal lamiid phylogeny and the circumscription of Icacinaceae with a plastome-scale dataset. Amer. J. Bot. 102: 1794-1813. http://dx.doi.org/10.3732/ajb.1500298

Stutzman, J.K., Lickey, E.B., Weeks, A. \& McMullen, C.K. 2012 . A taxonomic study of the Galapagos endemic Varronia (Cordiaceae) species with nomenclatural notes. J. Bot. Res. Inst. Texas 6: 75-99.

Sullivan, G.A. 2001. Hydrophyllaceae. Pp. 1154-1156 in: Stevens, W.D., Ulloa Ulloa, C., Pool, A. \& Montiel, M. (eds.), Flora de Nicaragua, vol. 2. St. Louis, Missouri: Missouri Botanical Garden.

Svensson, H.G. 1925. Zur Embryologie der Hydrophyllaceen, Borraginaceen und Heliotropiaceen mit besonderer Rücksicht auf die Endospermbildung. Uppsala Univ. Arsskr. 2: 3-175.

Takhtajan, A.L. 1980. Outline of the classification of flowering plants (Magnoliophyta). Bot. Rev. (Lancaster) 46: 225-359. http://dx.doi.org/10.1007/BF02861558

Takhtajan, A. 1987. Systema Magnoliophytorum. Leningrad: Oficina Editoria NAUKA. [in Russian]

Takhtajan, A. 1997. Diversity and classification of flowering plants. New York: Columbia University Press.

Takhtajan, A. 2009. Flowering plants, ed. 2. New York: Springer. http://dx.doi.org/10.1007/978-1-4020-9609-9

Taylor, S.E. 2012. Molecular systematics and the origins of gypsophily in Nama L. (Boraginaceae). Dissertation, University of Texas, Austin, Texas, U.S.A.

Thorne, R.F. 1992. Classification and geography of the flowering plants. Bot. Rev. (Lancaster) 58: 225-327. http://dx.doi.org/10.1007/BF02858611

Thulin, M. 1998. A new species of Wellstedia (Boraginaceae) from Somalia. Nordic J. Bot. 18: 663-665. http://dx.doi.org/10.1111/j.1756-1051.1998.tb01530.x 
Thulin, M. \& Johansson, N.B. 1996. Taxonomy and biogeography of the anomalous genus Wellstedia. Pp. 73-86 in: Van der Maesen, L.J.G., Van der Burgt, M. \& Van Madenbach de Rooy, J.M. (eds.), The biodiversity of African plants. Dordrecht: Kluwer Academic Publishers. http://dx.doi.org/10.1007/978-94-009-0285-5_11

Tölke, E.E.A.D., Melo, J.I.M. de., Carmello-Guerreiro, S.M. \& Lacchia, A.P.S. 2013. Leaf anatomy with emphasis on separation of two species of Varronia P.Br. (Cordiaceae) of the Brazilian semiarid region. Brazil. J. Bot. 36: 189-201.

Véliz Pérez, M.E., Campos-Ríos, M.G. \& Miller, J.S. 2009. Especie nueva del género Bourreria (Ehretiaceae, Boraginales) de Mesoamérica. Brittonia 61: 237-240. http://dx.doi.org/10.1007/s12228-009-9080-1

Vences, M., Guayasamin, J.M., Miralles, A. \& De la Riva, I. 2013. To name or not to name: Criteria to promote economy of change in Linnaean classification schemes. Zootaxa 3636: 201-244. http://dx.doi.org/10.11646/zootaxa.3636.2.1
Venkateswarlu, J. \& Atchutaramanurti, B. 1955. Embryological Studies in Boraginaceæ. I. - Coldenia procumbens Linn. J. Indian Bot. Soc. 34: 235-247.

Wagenitz, G. 1964. Ebenales. Pp. 396-403 in: Melchior, H. (ed.), A. Engler's Syllabus der Pflanzenfamilien, vol. 2. Berlin: Gebrüder Borntraeger.

Walden, G.K. 2010. Phylogeny of infrageneric relationships within Phacelia (Boraginaceae) inferred from chloroplast sequence data. M.Sc. Thesis, San Francisco State University, San Francisco, California, U.S.A.

Walden, G.K. 2015. Systematics of Emmenanthe, Eucrypta, and Phacelia sect. Ramosissimae (Hydrophyllaceae; Boraginales). Dissertation, University of California, Berkeley, San Francisco, California, U.S.A.

Walden, G.K. \& Patterson, R. 2012. Nomenclature of subdivisions within Phacelia (Boraginaceae: Hydrophylloideae). Madroño 59: 211-222. http://dx.doi.org/10.3120/0024-9637-59.4.211

Appendix 1. Systematics of Boraginales according to different authors.

\begin{tabular}{|c|c|c|c|c|}
\hline This work & $\begin{array}{l}\text { Jussieu } \\
(1789)\end{array}$ & $\begin{array}{l}\text { Berchtold \& Presl } \\
(1820)\end{array}$ & $\begin{array}{l}\text { Dumortier } \\
(1829)\end{array}$ & $\begin{array}{l}\text { Lindley } \\
(1831)\end{array}$ \\
\hline$\overline{\text { Codonaceae }}$ & $?$ & $?$ & - & - \\
\hline Wellstediaceae & - & - & - & - \\
\hline Boraginaceae & Boraginaceae II, III, IV & Boraginales & $\begin{array}{l}\text { Boraginaceae - Lithospermeae, } \\
\text { Boraginaceae - Cerintheae, } \\
\text { Boraginaceae - Echieae } \\
\text { (Boraginales) }\end{array}$ & Boraginaceae \\
\hline Hydrophyllaceae & Boraginaceae II & Ellisiales & $\begin{array}{l}\text { Hydrophyllaceae } \\
\text { (Boraginales) }\end{array}$ & Hydrophyllaceae \\
\hline Namaceae & Convolvulaceae & Hydroleales & $\begin{array}{l}\text { Hydroleaceae } \\
\text { (Convolvulales) }\end{array}$ & Hydroleaceae \\
\hline Heliotropiaceae & Boraginaceae I, II, III & Boraginales & $\begin{array}{l}\text { Boraginaceae - Heliotropieae } \\
\text { (Boraginales) }\end{array}$ & Heliotropiaceae/Ehretiaceae \\
\hline Ehretiaceae & Boraginaceae I & Boraginales & $\begin{array}{l}\text { Cordiaceae - Ehretieae } \\
\text { (Boraginales) }\end{array}$ & Ehretiaceae \\
\hline Lennoaceae & - & - & - & - \\
\hline Coldeniaceae & Boraginaceae III & Boraginales & $\begin{array}{l}\text { Boraginaceae - Heliotropieae } \\
\text { (Boraginales) }\end{array}$ & $?$ \\
\hline Hoplestigmataceae & - & - & - & - \\
\hline Cordiaceae & Boraginaceae I & Sebestanales & $\begin{array}{l}\text { Cordiaceae - Cordieae } \\
\text { (Boraginales) }\end{array}$ & Cordiaceae \\
\hline [Hydroleaceae (Solanales)] & Convolvulaceae & Hydroleales & Hydroleaceae (Convolvulales) & Hydroleaceae \\
\hline
\end{tabular}

[Tetrachondraceae (Lamiales)] - 
Walden, G.K., Garrison, L.M., Spicer, G.S., Cipriano, F.W. \& Patterson, R. 2014. Phylogenies and chromosome evolution of Phacelia (Boraginaceae: Hydrophylloideae) inferred from nuclear ribosomal and chloroplast sequence data. Madroño 61: 16-47. http://dx.doi.org/10.3120/0024-9637-61.1.16

Weeks, A., Baird, K.E. \& McMullen, C.K. 2010. Origin and evolution of endemic Galápagos Varronia species (Cordiaceae). Molec. Phylogen. Evol. 57: 948-954. http://dx.doi.org/10.1016/j.ympev.2010.08.014

Weigend, M. \& Hilger, H.H. 2010. Codonaceae - A newly required family name in Boraginales. Phytotaxa 10: 26-30. http://dx.doi.org/10.11646/phytotaxa.10.1.3

Weigend, M., Luebert, F., Selvi, F., Brokamp, G. \& Hilger, H.H. 2013. Multiple origins for Hound's tongues (Cynoglossum L.) and Navel seeds (Omphalodes Mill.) - The phylogeny of the borage family (Boraginaceae s.str.). Molec. Phylogen. Evol. 68: 604-618. http://dx.doi.org/10.1016/j.ympev.2013.04.009
Weigend, M., Luebert, F., Gottschling, M., Couvreur, T.L.P., Hilger, H.H. \& Miller, J.S. 2014. From capsules to nutlets - Phylogenetic relationships in the Boraginales. Cladistics 30: 508-518. http://dx.doi.org/10.1111/cla.12061

Yatskievych, G. 2001. Lennoaceae. Pp. 1213-1214 in: Stevens, W.D., Ulloa Ulloa, C., Pool, A. \& Montiel, M. (eds.), Flora de Nicaragua, vol. 2. St. Louis: Missouri Botanical Garden.

Yatskievych, G. 2012. Lennoaceae. Pp. 309-310 in: Davidse, G., Sousa Sánchez, M., Knapp, S. \& Chiang Cabrera, F. (eds.), Flora Mesoamericana, vol. 4(2). St. Louis: Missouri Botanical Garden Press.

Yatskievych, G. \& Mason, C.T. 1986. A revision of the Lennoaceae. Syst. Bot. 11: 531-548. http://dx.doi.org/10.2307/2419032

Appendix 1. Continued.

\begin{tabular}{|c|c|c|c|c|}
\hline This work & $\begin{array}{l}\text { Endlicher } \\
(1836)\end{array}$ & $\begin{array}{l}\text { Candolle } \\
(1845,1846,1873)\end{array}$ & $\begin{array}{l}\text { Bentham \& Hooker } \\
(1876)\end{array}$ & $\begin{array}{l}\text { Baillon } \\
(1891) \\
\end{array}$ \\
\hline Codonaceae & $\begin{array}{l}\text { Hydroleaceae } \\
\text { (Tubiflorae) }\end{array}$ & ?Hydroleaceae & $\begin{array}{l}\text { Hydrophyllaceae - Phace- } \\
\text { lieae (Polemoniales) }\end{array}$ & Boraginaceae - Phacelieae \\
\hline Wellstediaceae & - & - & - & - \\
\hline Boraginaceae & $\begin{array}{l}\text { Asperifoliaceae - Boragineae } \\
\text { (Nuculiferae) }\end{array}$ & $\begin{array}{l}\text { Boraginaceae - Boragineae, } \\
\text { Cerintheae, Echieae, Litho- } \\
\text { spermeae, Craniospermeae, } \\
\text { Anchuseae, Cynoglosseae }\end{array}$ & $\begin{array}{l}\text { Boraginaceae - Boragineae } \\
\text { (Polemoniales) }\end{array}$ & $\begin{array}{l}\text { Boraginaceae - Boragineae, } \\
\text { Boraginaceae - Echieae, } \\
\text { Boraginaceae - Harpagonelleae }\end{array}$ \\
\hline Hydrophyllaceae & $\begin{array}{l}\text { Hydrophyllaceae } \\
\text { (Tubiflorae) }\end{array}$ & Hydrophyllaceae & $\begin{array}{l}\text { Hydrophyllaceae - Hydro- } \\
\text { phylleae, Hydrophyllaceae - } \\
\text { Phacelieae (Polemoniales) }\end{array}$ & $\begin{array}{l}\text { Boraginaceae - Hydrophylleae, } \\
\text { Boraginaceae - Phacelieae }\end{array}$ \\
\hline Namaceae & $\begin{array}{l}\text { Hydroleaceae } \\
\text { (Tubiflorae) }\end{array}$ & Hydroleaceae-Nameae & $\begin{array}{l}\text { Hydrophyllaceae - Nameae } \\
\text { (Polemoniales) }\end{array}$ & Boraginaceae - Phacelieae \\
\hline Heliotropiaceae & $\begin{array}{l}\text { Asperifoliaceae - Ehretieae } \\
\text { (Nuculiferae) }\end{array}$ & $\begin{array}{l}\text { Boraginaceae - Ehretieae, } \\
\text { Boraginaceae - Heliotropieae }\end{array}$ & $\begin{array}{l}\text { Boraginaceae - Helio- } \\
\text { tropieae (Polemoniales) }\end{array}$ & Boraginaceae - Heliotropieae \\
\hline Ehretiaceae & $\begin{array}{l}\text { Asperifoliaceae - Ehretieae } \\
\text { (Nuculiferae) }\end{array}$ & Boraginaceae - Ehretieae & $\begin{array}{l}\text { Boraginaceae - Ehretieae } \\
\text { (Polemoniales) }\end{array}$ & Boraginaceae - Ehretieae \\
\hline Lennoaceae & dubiae sedis & Lennoaceae & $\begin{array}{l}\text { Lennoaceae } \\
\text { (Ericales) }\end{array}$ & \\
\hline Coldeniaceae & $\begin{array}{l}\text { Asperifoliaceae - Ehretieae } \\
\text { (Nuculiferae) }\end{array}$ & Boraginaceae - Heliotropieae & $\begin{array}{l}\text { Boraginaceae - Ehretieae } \\
\text { (Polemoniales) }\end{array}$ & Boraginaceae - Ehretieae \\
\hline Hoplestigmataceae & - & - & - & - \\
\hline Cordiaceae & $\begin{array}{l}\text { Cordiaceae } \\
\text { (Nuculiferae) }\end{array}$ & Boraginaceae - Cordieae & $\begin{array}{l}\text { Boraginaceae - Cordieae } \\
\text { (Polemoniales) }\end{array}$ & Boraginaceae - Cordieae \\
\hline [Hydroleaceae (Solanales)] & $\begin{array}{l}\text { Hydroleaceae } \\
\text { (Tubiflorae) }\end{array}$ & Hydroleaceae - Hydroleae & $\begin{array}{l}\text { Hydrophyllaceae - Hydro- } \\
\text { leae (Polemoniales) }\end{array}$ & Boraginaceae - Hydroleae \\
\hline [Tetrachondraceae (Lamiales)] & - & - & - & - \\
\hline
\end{tabular}


Appendix 1. Continued.

\begin{tabular}{|c|c|c|c|c|}
\hline This work & $\begin{array}{l}\text { Engler } \\
(1893,1908,1915)\end{array}$ & $\begin{array}{l}\text { Engler } \\
(1898)\end{array}$ & $\begin{array}{l}\text { Chadefaud \& Emberger } \\
(1960)\end{array}$ & $\begin{array}{l}\text { Takhtajan } \\
(1980)\end{array}$ \\
\hline Codonaceae & $\begin{array}{l}\text { Hydrophyllaceae - } \\
\text { Phacelieae }\end{array}$ & $\begin{array}{l}\text { Hydrophyllaceae - Phacelieae } \\
\text { (Boraginineae) }\end{array}$ & $\begin{array}{l}\text { Hydrophyllaceae } \\
\text { (Tubiflorales) }\end{array}$ & $\begin{array}{l}\text { Hydrophyllaceae } \\
\text { (Boraginineae - Polemoniales) }\end{array}$ \\
\hline Wellstediaceae & $\begin{array}{l}\text { Boraginaceae - } \\
\text { Wellstedioideae }\end{array}$ & - & $\begin{array}{l}\text { Boraginaceae - Wellstedi- } \\
\text { oideae (Tubiflorales) }\end{array}$ & $\begin{array}{l}\text { Boraginaceae } \\
\text { (Boraginineae - Polemoniales) }\end{array}$ \\
\hline Boraginaceae & $\begin{array}{l}\text { Boraginaceae - } \\
\text { Boraginoideae }\end{array}$ & $\begin{array}{l}\text { Boraginaceae - Boraginoideae } \\
\text { (Boraginineae) }\end{array}$ & $\begin{array}{l}\text { Boraginaceae - Boraginoideae } \\
\text { (Tubiflorales) }\end{array}$ & $\begin{array}{l}\text { Boraginaceae } \\
\text { (Boraginineae - Polemoniales) }\end{array}$ \\
\hline Hydrophyllaceae & $\begin{array}{l}\text { Hydrophyllaceae - } \\
\text { Hydrophylleae, } \\
\text { Hydrophyllaceae - } \\
\text { Phacelieae }\end{array}$ & $\begin{array}{l}\text { Hydrophyllaceae - } \\
\text { Hydrophylleae, } \\
\text { Hydrophyllaceae - } \\
\text { Phacelieae (Boraginineae) }\end{array}$ & $\begin{array}{l}\text { Hydrophyllaceae } \\
\text { (Tubiflorales) }\end{array}$ & $\begin{array}{l}\text { Hydrophyllaceae } \\
\text { (Boraginineae - Polemoniales) }\end{array}$ \\
\hline Namaceae & $\begin{array}{l}\text { Hydrophyllaceae - } \\
\text { Nameae }\end{array}$ & $\begin{array}{l}\text { Hydrophyllaceae - Nameae } \\
\text { (Boraginineae) }\end{array}$ & $\begin{array}{l}\text { Hydrophyllaceae } \\
\text { (Tubiflorales) }\end{array}$ & $\begin{array}{l}\text { Hydrophyllaceae } \\
\text { (Boraginineae - Polemoniales) }\end{array}$ \\
\hline Heliotropiaceae & $\begin{array}{l}\text { Boraginaceae - } \\
\text { Heliotropioideae }\end{array}$ & $\begin{array}{l}\text { Boraginaceae - Heliotro- } \\
\text { pioideae (Boraginineae) }\end{array}$ & $\begin{array}{l}\text { Boraginaceae - Heliotropi- } \\
\text { oideae (Tubiflorales) }\end{array}$ & $\begin{array}{l}\text { Boraginaceae } \\
\text { (Boraginineae - Polemoniales) }\end{array}$ \\
\hline Ehretiaceae & $\begin{array}{l}\text { Boraginaceae - } \\
\text { Ehretioideae }\end{array}$ & $\begin{array}{l}\text { Boraginaceae - Ehretioideae } \\
\text { (Boraginineae) }\end{array}$ & $\begin{array}{l}\text { Boraginaceae - Ehretioideae } \\
\text { (Tubiflorales) }\end{array}$ & $\begin{array}{l}\text { Boraginaceae } \\
\text { (Boraginineae - Polemoniales) }\end{array}$ \\
\hline Lennoaceae & Lennoaceae & Lennoaceae (Ericales) & $\begin{array}{l}\text { Lennoaceae } \\
\text { (Tubiflorales) }\end{array}$ & $\begin{array}{l}\text { Lennoaceae } \\
\text { (Boraginineae - Polemoniales) }\end{array}$ \\
\hline Coldeniaceae & $\begin{array}{l}\text { Boraginaceae - } \\
\text { Ehretioideae }\end{array}$ & $\begin{array}{l}\text { Boraginaceae - ?Ehretioideae } \\
\text { (Boraginineae) }\end{array}$ & $\begin{array}{l}\text { Boraginaceae - Ehretioideae } \\
\text { (Tubiflorales) }\end{array}$ & $\begin{array}{l}\text { Boraginaceae (Boraginineae } \\
\text { - Polemoniales) }\end{array}$ \\
\hline Hoplestigmataceae & Hoplestigmataceae & - & $\begin{array}{l}\text { Hoplestigmataceae } \\
\text { (Tubiflorales) }\end{array}$ & $\begin{array}{l}\text { Hoplestigmataceae } \\
\text { (Boraginineae - Polemoniales) }\end{array}$ \\
\hline Cordiaceae & $\begin{array}{l}\text { Boraginaceae - } \\
\text { Cordioideae }\end{array}$ & $\begin{array}{l}\text { Boraginaceae - Cordioideae } \\
\text { (Boraginineae) }\end{array}$ & $\begin{array}{l}\text { Boraginaceae - Cordioideae } \\
\text { (Tubiflorales) }\end{array}$ & $\begin{array}{l}\text { Boraginaceae (Boraginineae } \\
\text { - Polemoniales) }\end{array}$ \\
\hline [Hydroleaceae (Solanales)] & $\begin{array}{l}\text { Hydrophyllaceae - } \\
\text { Hydroleae }\end{array}$ & $\begin{array}{l}\text { Hydrophyllaceae - Hydroleae } \\
\text { (Boraginineae) }\end{array}$ & $\begin{array}{l}\text { Hydrophyllaceae - Hydroleae } \\
\text { (Tubiflorales) }\end{array}$ & $\begin{array}{l}\text { Hydrophyllaceae (Boraginineae } \\
\text { - Polemoniales) }\end{array}$ \\
\hline [Tetrachondraceae (Lamiales)] & - & - & $\begin{array}{l}\text { Tetrachondraceae } \\
\text { (Tubiflorales) }\end{array}$ & ?Lamiaceae (Lamiales) \\
\hline This work & $\begin{array}{l}\text { Dahlgren } \\
(1980)\end{array}$ & $\begin{array}{l}\text { Cronquist } \\
(1981,1988)\end{array}$ & $\begin{array}{l}\text { Takhtajan } \\
(1987)\end{array}$ & $\begin{array}{l}\text { Thorne } \\
\text { (1992) }\end{array}$ \\
\hline Codonaceae & $\begin{array}{l}\text { Hydrophyllaceae } \\
\text { (Boraginales) }\end{array}$ & $\begin{array}{l}\text { Hydrophyllaceae } \\
\text { (Solanales) }\end{array}$ & $\begin{array}{l}\text { Hydrophyllaceae } \\
\text { (Boraginales) }\end{array}$ & $\begin{array}{l}\text { Hydrophyllaceae } \\
\text { (Boraginineae - Solanales) }\end{array}$ \\
\hline Wellstediaceae & $\begin{array}{l}\text { Wellstediaceae } \\
\text { (Boraginales) }\end{array}$ & $\begin{array}{l}\text { Boraginaceae } \\
\text { (Lamiales) }\end{array}$ & $\begin{array}{l}\text { Wellstediaceae } \\
\text { (Boraginales) }\end{array}$ & $\begin{array}{l}\text { Boraginaceae } \\
\text { (Boraginineae - Solanales) }\end{array}$ \\
\hline Boraginaceae & $\begin{array}{l}\text { Boraginaceae } \\
\text { (Boraginales) }\end{array}$ & $\begin{array}{l}\text { Boraginaceae } \\
\text { (Lamiales) }\end{array}$ & $\begin{array}{l}\text { Boraginaceae } \\
\text { (Boraginales) }\end{array}$ & $\begin{array}{l}\text { Boraginaceae } \\
\text { (Boraginineae - Solanales) }\end{array}$ \\
\hline Hydrophyllaceae & $\begin{array}{l}\text { Hydrophyllaceae } \\
\text { (Boraginales) }\end{array}$ & $\begin{array}{l}\text { Hydrophyllaceae } \\
\text { (Solanales) }\end{array}$ & $\begin{array}{l}\text { Hydrophyllaceae } \\
\text { (Boraginales) }\end{array}$ & $\begin{array}{l}\text { Hydrophyllaceae } \\
\text { (Boraginineae - Solanales) }\end{array}$ \\
\hline Namaceae & $\begin{array}{l}\text { Hydrophyllaceae } \\
\text { (Boraginales) }\end{array}$ & $\begin{array}{l}\text { Hydrophyllaceae } \\
\text { (Solanales) }\end{array}$ & $\begin{array}{l}\text { Hydrophyllaceae } \\
\text { (Boraginales) }\end{array}$ & $\begin{array}{l}\text { Hydrophyllaceae } \\
\text { (Boraginineae - Solanales) }\end{array}$ \\
\hline Heliotropiaceae & $\begin{array}{l}\text { Boraginaceae } \\
\text { (Boraginales) }\end{array}$ & $\begin{array}{l}\text { Boraginaceae } \\
\text { (Lamiales) }\end{array}$ & $\begin{array}{l}\text { Boraginaceae } \\
\text { (Boraginales) }\end{array}$ & $\begin{array}{l}\text { Boraginaceae } \\
\text { (Boraginineae - Solanales) }\end{array}$ \\
\hline Ehretiaceae & $\begin{array}{l}\text { Ehretiaceae } \\
\text { (Boraginales) }\end{array}$ & $\begin{array}{l}\text { Boraginaceae } \\
\text { (Lamiales) }\end{array}$ & $\begin{array}{l}\text { Ehretiaceae } \\
\text { (Boraginales) }\end{array}$ & $\begin{array}{l}\text { Boraginaceae } \\
\text { (Boraginineae - Solanales) }\end{array}$ \\
\hline Lennoaceae & $\begin{array}{l}\text { Lennoaceae } \\
\text { (Boraginales) }\end{array}$ & $\begin{array}{l}\text { Lennoaceae } \\
\text { (Lamiales) }\end{array}$ & $\begin{array}{l}\text { Lennoaceae } \\
\text { (Boraginales) }\end{array}$ & $\begin{array}{l}\text { Lennoaceae } \\
\text { (Boraginineae - Solanales) }\end{array}$ \\
\hline Coldeniaceae & $\begin{array}{l}\text { Ehretiaceae } \\
\text { (Boraginales) }\end{array}$ & $\begin{array}{l}\text { Boraginaceae } \\
\text { (Lamiales) }\end{array}$ & $\begin{array}{l}\text { Ehretiaceae } \\
\text { (Boraginales) }\end{array}$ & $\begin{array}{l}\text { Boraginaceae } \\
\text { (Boraginineae - Solanales) }\end{array}$ \\
\hline Hoplestigmataceae & $\begin{array}{l}\text { Hoplestigmataceae } \\
\text { (Boraginales) }\end{array}$ & $\begin{array}{l}\text { Hoplestigmataceae } \\
\text { (Violales) }\end{array}$ & $\begin{array}{l}\text { Hoplestigmataceae } \\
\text { (Boraginales) }\end{array}$ & $\begin{array}{l}\text { Hoplestigmataceae } \\
\text { (Boraginineae - Solanales) }\end{array}$ \\
\hline Cordiaceae & $\begin{array}{l}\text { Ehretiaceae } \\
\text { (Boraginales) }\end{array}$ & $\begin{array}{l}\text { Boraginaceae } \\
\text { (Lamiales) }\end{array}$ & $\begin{array}{l}\text { Cordiaceae } \\
\text { (Boraginales) }\end{array}$ & $\begin{array}{l}\text { Boraginaceae } \\
\text { (Boraginineae - Solanales) }\end{array}$ \\
\hline [Hydroleaceae (Solanales)] & $\begin{array}{l}\text { Hydrophyllaceae } \\
\text { (Boraginales) }\end{array}$ & $\begin{array}{l}\text { Hydrophyllaceae } \\
\text { (Solanales) }\end{array}$ & $\begin{array}{l}\text { Hydrophyllaceae } \\
\text { (Boraginales) }\end{array}$ & $\begin{array}{l}\text { Hydrophyllaceae } \\
\text { (Boraginineae - Solanales) }\end{array}$ \\
\hline [Tetrachondraceae (Lamiales)] & $?$ & $\begin{array}{l}\text { Lamiaceae } \\
\text { (Lamiales) }\end{array}$ & $\begin{array}{l}\text { Lamiaceae } \\
\text { (Lamiales) }\end{array}$ & $\begin{array}{l}\text { Tetrachondraceae } \\
\text { (Boraginineae - Solanales) }\end{array}$ \\
\hline
\end{tabular}


Appendix 1. Continued.

\begin{tabular}{|c|c|c|c|c|}
\hline This work & $\begin{array}{l}\text { Takhtajan } \\
(1997)\end{array}$ & $\begin{array}{l}\text { APG (1998, 2003); } \\
\text { Mabberley (2008) }\end{array}$ & $\begin{array}{l}\text { Takhtajan } \\
(2009)\end{array}$ & $\begin{array}{l}\text { APG } \\
(2009)\end{array}$ \\
\hline Codonaceae & $\begin{array}{l}\text { Hydrophyllaceae } \\
\text { (Boraginales) }\end{array}$ & $\begin{array}{l}\text { Boraginaceae } \\
\text { (Euasterids I unplaced) }\end{array}$ & $\begin{array}{l}\text { Hydrophyllaceae - Codon- } \\
\text { oideae (Boraginales) }\end{array}$ & $\begin{array}{l}\text { Boraginaceae } \\
\text { (lamiids unplaced) }\end{array}$ \\
\hline Wellstediaceae & $\begin{array}{l}\text { Boraginaceae } \\
\text { (Boraginales) }\end{array}$ & $\begin{array}{l}\text { Boraginaceae } \\
\text { (Euasterids I unplaced) }\end{array}$ & $\begin{array}{l}\text { Boraginaceae - Wellstedi- } \\
\text { oideae (Boraginales) }\end{array}$ & $\begin{array}{l}\text { Boraginaceae } \\
\text { (lamiids unplaced) }\end{array}$ \\
\hline Boraginaceae & $\begin{array}{l}\text { Boraginaceae } \\
\text { (Boraginales) }\end{array}$ & $\begin{array}{l}\text { Boraginaceae } \\
\text { (Euasterids I unplaced) }\end{array}$ & $\begin{array}{l}\text { Boraginaceae - Boragin- } \\
\text { oideae (Boraginales) }\end{array}$ & $\begin{array}{l}\text { Boraginaceae } \\
\text { (lamiids unplaced) }\end{array}$ \\
\hline Hydrophyllaceae & $\begin{array}{l}\text { Hydrophyllaceae } \\
\text { (Boraginales) }\end{array}$ & $\begin{array}{l}\text { Boraginaceae } \\
\text { (Euasterids I unplaced) }\end{array}$ & $\begin{array}{l}\text { Hydrophyllaceae - Hydro- } \\
\text { phylloideae (Boraginales) }\end{array}$ & $\begin{array}{l}\text { Boraginaceae } \\
\text { (lamiids unplaced) }\end{array}$ \\
\hline Namaceae & $\begin{array}{l}\text { Hydrophyllaceae } \\
\text { (Boraginales) }\end{array}$ & $\begin{array}{l}\text { Boraginaceae } \\
\text { (Euasterids I unplaced) }\end{array}$ & $\begin{array}{l}\text { Hydrophyllaceae - Hydro- } \\
\text { phylloideae (Boraginales) }\end{array}$ & $\begin{array}{l}\text { Boraginaceae } \\
\text { (lamiids unplaced) }\end{array}$ \\
\hline Heliotropiaceae & $\begin{array}{l}\text { Boraginaceae } \\
\text { (Boraginales) }\end{array}$ & $\begin{array}{l}\text { Boraginaceae } \\
\text { (Euasterids I unplaced) }\end{array}$ & $\begin{array}{l}\text { Boraginaceae - Heliotropi- } \\
\text { oideae (Boraginales) }\end{array}$ & $\begin{array}{l}\text { Boraginaceae } \\
\text { (lamiids unplaced) }\end{array}$ \\
\hline Ehretiaceae & $\begin{array}{l}\text { Boraginaceae } \\
\text { (Boraginales) }\end{array}$ & $\begin{array}{l}\text { Boraginaceae } \\
\text { (Euasterids I unplaced) }\end{array}$ & $\begin{array}{l}\text { Boraginaceae - Ehreti- } \\
\text { oideae (Boraginales) }\end{array}$ & $\begin{array}{l}\text { Boraginaceae } \\
\text { (lamiids unplaced) }\end{array}$ \\
\hline Lennoaceae & $\begin{array}{l}\text { Lennoaceae } \\
\text { (Boraginales) }\end{array}$ & $\begin{array}{l}\text { Boraginaceae } \\
\text { (Euasterids I unplaced) }\end{array}$ & $\begin{array}{l}\text { Lennoaceae } \\
\text { (Boraginales) }\end{array}$ & $\begin{array}{l}\text { Boraginaceae } \\
\text { (lamiids unplaced) }\end{array}$ \\
\hline Coldeniaceae & $\begin{array}{l}\text { Boraginaceae } \\
\text { (Boraginales) }\end{array}$ & $\begin{array}{l}\text { Boraginaceae } \\
\text { (Euasterids I unplaced) }\end{array}$ & $\begin{array}{l}\text { Boraginaceae - Ehreti- } \\
\text { oideae (Boraginales) }\end{array}$ & $\begin{array}{l}\text { Boraginaceae } \\
\text { (lamiids unplaced) }\end{array}$ \\
\hline Hoplestigmataceae & $\begin{array}{l}\text { Hoplestigmataceae } \\
\text { (Boraginales) }\end{array}$ & $\begin{array}{l}\text { Hoplestigmataceae } \\
\text { (unplaced) }\end{array}$ & $\begin{array}{l}\text { Hoplestigmataceae } \\
\text { (Boraginales) }\end{array}$ & $\begin{array}{l}\text { Boraginaceae } \\
\text { (lamiids unplaced) }\end{array}$ \\
\hline Cordiaceae & $\begin{array}{l}\text { Boraginaceae } \\
\text { (Boraginales) }\end{array}$ & $\begin{array}{l}\text { Boraginaceae } \\
\text { (Euasterids I unplaced) }\end{array}$ & $\begin{array}{l}\text { Boraginaceae - Cordio- } \\
\text { ideae (Boraginales) }\end{array}$ & $\begin{array}{l}\text { Boraginaceae } \\
\text { (lamiids unplaced) }\end{array}$ \\
\hline [Hydroleaceae (Solanales)] & $\begin{array}{l}\text { Hydrophyllaceae } \\
\text { (Boraginales) }\end{array}$ & Hydroleaceae (Solanales) & $\begin{array}{l}\text { Hydroleaceae } \\
\text { (Solanales) }\end{array}$ & $\begin{array}{l}\text { Hydroleaceae } \\
\text { (Solanales) }\end{array}$ \\
\hline [Tetrachondraceae (Lamiales)] & $\begin{array}{l}\text { Tetrachondraceae } \\
\text { (Boraginales) }\end{array}$ & $\begin{array}{l}\text { Tetrachondraceae } \\
\text { (Lamiales) }\end{array}$ & $\begin{array}{l}\text { Tetrachondraceae } \\
\text { (Lamiales) }\end{array}$ & $\begin{array}{l}\text { Tetrachondraceae } \\
\text { (Lamiales) }\end{array}$ \\
\hline This work & $\begin{array}{l}\text { Reveal \& Chase } \\
(2011)\end{array}$ & $\begin{array}{l}\text { Reveal } \\
(2011,2012)\end{array}$ & & \\
\hline Codonaceae & $\begin{array}{l}\text { Boraginaceae } \\
\text { (Boraginales) }\end{array}$ & $\begin{array}{l}\text { Boraginaceae - Codonoideae } \\
\text { (Boraginineae - Solanales) }\end{array}$ & & \\
\hline Wellstediaceae & $\begin{array}{l}\text { Boraginaceae } \\
\text { (Boraginales) }\end{array}$ & $\begin{array}{l}\text { Boraginaceae - Wellstedioideae } \\
\text { (Boraginineae - Solanales) }\end{array}$ & & \\
\hline Boraginaceae & $\begin{array}{l}\text { Boraginaceae } \\
\text { (Boraginales) }\end{array}$ & $\begin{array}{l}\text { Boraginaceae - Boraginoideae } \\
\text { (Boraginineae - Solanales) }\end{array}$ & & \\
\hline Hydrophyllaceae & $\begin{array}{l}\text { Boraginaceae } \\
\text { (Boraginales) }\end{array}$ & $\begin{array}{l}\text { Boraginaceae - Hydrophylloideae } \\
\text { (Boraginineae - Solanales) }\end{array}$ & & \\
\hline Namaceae & $\begin{array}{l}\text { Boraginaceae } \\
\text { (Boraginales) }\end{array}$ & $\begin{array}{l}\text { Boraginaceae - Hydrophylloideae } \\
\text { (Boraginineae - Solanales) }\end{array}$ & & \\
\hline Heliotropiaceae & $\begin{array}{l}\text { Boraginaceae } \\
\text { (Boraginales) }\end{array}$ & $\begin{array}{l}\text { Boraginaceae - Heliotropiodeae } \\
\text { (Boraginineae - Solanales) }\end{array}$ & & \\
\hline Ehretiaceae & $\begin{array}{l}\text { Boraginaceae } \\
\text { (Boraginales) }\end{array}$ & $\begin{array}{l}\text { Boraginaceae - Ehretioideae } \\
\text { (Boraginineae - Solanales) }\end{array}$ & & \\
\hline Lennoaceae & $\begin{array}{l}\text { Boraginaceae } \\
\text { (Boraginales) }\end{array}$ & $\begin{array}{l}\text { Boraginaceae - Lennooideae } \\
\text { (Boraginineae - Solanales) }\end{array}$ & & \\
\hline Coldeniaceae & $\begin{array}{l}\text { Boraginaceae } \\
\text { (Boraginales) }\end{array}$ & $\begin{array}{l}\text { Boraginaceae } \\
\text { (Boraginineae - Solanales) }\end{array}$ & & \\
\hline Hoplestigmataceae & $\begin{array}{l}\text { Boraginaceae } \\
\text { (Boraginales) }\end{array}$ & $\begin{array}{l}\text { Boraginaceae - Cordioideae } \\
\text { (Boraginineae - Solanales) }\end{array}$ & & \\
\hline Cordiaceae & $\begin{array}{l}\text { Boraginaceae } \\
\text { (Boraginales) }\end{array}$ & $\begin{array}{l}\text { Boraginaceae - Cordioideae } \\
\text { (Boraginineae - Solanales) }\end{array}$ & & \\
\hline [Hydroleaceae (Solanales)] & $\begin{array}{l}\text { Hydroleaceae } \\
\text { (Lamiales) }\end{array}$ & $\begin{array}{l}\text { Hydroleaceae } \\
\text { (Solanineae - Solanales) }\end{array}$ & & \\
\hline [Tetrachondraceae (Lamiales)] & $\begin{array}{l}\text { Tetrachondraceae } \\
\text { (Lamiales) }\end{array}$ & $\begin{array}{l}\text { Tetrachondraceae } \\
\text { (Gesneriineae - Lamiales) }\end{array}$ & & \\
\hline
\end{tabular}


Appendix 2. Accepted genera of Boraginales (bold) and generic synonyms (regular). Number of species and distribution are indicated for each accepted genus. Number of genera/number of species is indicated for families. Only valid generic names are included. Orthographic variations and genera originally published under a family of Boraginales, but currently in a different order, are excluded. * indicates genera or synonyms not yet verified by molecular data. Abbreviations: Afr: Africa; Am: America; Arab: Arabian Peninsula; Aus: Australia; Cal: California; Eur: Europe; Ind: India; Med: Mediterranean region; Neotrop: Neotropical; pantrop: pantropical; subcsmop: subcosmopolitan; trop: tropical.

BORAGINACEAE Juss. ( 90/ 1600-1700)

Actinocarya Benth. $=$ Microula

*Adelinia J.I.Cohen (1) N Am

*Adelocaryum Brand (3) Arab \& Ind

Aegonychon Gray (3) Asia \& Eur

*Afrotysonia Rauschert (3) E Afr

Aipyanthus Steven $=$ Huynhia

Alkanna Tausch ( 40) Med \& SW Asia

Allocarya Greene $=$ Plagiobothrys

Allocaryastrum Brand = Plagiobothrys

Amblynotopsis J.F.Macbr. $=$ Antiphytum

Amblynotus I.M.Johnst. $=$ Eritrichium

Amphibologyne Brand = Antiphytum

Amsinckia Lehm. ( 15) N \& S Am

Anchusa L. ( 35) Afr, Eur, W Asia

Anchusella Bigazzi, Nardi \& Selvi (2) Med

Anchusopsis Bisch. $=$ Cynoglossum

Ancistrocarya Maxim. (1) Japan \& Korea

*Andersonglossum J.I.Cohen (3) N Am

Anisanthera Raf. $=$ Caccinia

Anoplocaryum Ledeb. (5) C Asia

Antiotrema Hand.-Mazz. (1) W China

Antiphytum DC. ex Meisn. (10) N \& S Am

Argyrexias Raf. $=$ Echium

Arnebia Forssk. ( 30) NE Afr, SE Eur, SW \&

C Asia

Arnebiola Chiov. $=$ Arnebia

Asperugo L. (1) Asia \& Eur

Austrocynoglossum Popov ex R.R.Mill = Hackelia

Baphorhiza Link = Alkanna

Batschia J.F.Gmel. $=$ Lithospermum

Bessera Schult. $=$ Pulmonaria

Bilegnum Brand $=$ Cynoglossum

Boraginella Siegesb. ex Kuntze $=$ Trichodesma

Boraginodes T.Post \& Kuntze $=$ Trichodesma

Borago L. (5) W Med

Borraginoides Moench $=$ Trichodesma

Bothriospermum Bunge (5) C \& E Asia

Brachybotrys Maxim. ex Oliv. (1) NE Asia

Brandella R.R.Mill = Microparacaryum

Brunnera Steven (3) W Asia \& SE Med

Buglossa Gray $=$ Lycopsis

Buglossites Moris = Borago

Buglossoides Moench (2) Eur, N Afr \& W Asia

Buglossum Mill. $=$ Anchusa

Caccinia Savi ( 6) Iran to S \& C Asia

Camptocarpus Decne. $=$ Alkanna

Campylocaryum DC. ex A.DC. $=$ Alkanna

Caryolopha Fisch. \& Trautv. $=$ Pentaglottis

Casselia Dumort. $=$ Mertensia

Cerinthe L. (7-10) Eur, NW Afr to W Asia

Cerinthodes Kuntze $=$ Mertensia

Cerinthopsis Kotschy ex Paine $=$ Cynoglossum

Cervia Rodrig. ex Lag. $=$ Rochelia

Chamissoniophila Brand $=$ Antiphytum

Chilechium Pfeiff. $=$ Echiochilon

Chilochium Raf. $=$ Echiochilon

Chionocharis I.M.Johnst. (1) C Asia

Choriantha Riedl $=$ Onosma

Colsmannia Lehm. $=$ Onosma

Craniospermum Lehm. (4-5) C \& E Asia

Crucicaryum Brand $=$ Cynoglossum

Cryptantha Lehm. ex G.Don $(\sim 160) \mathrm{N} \& \mathrm{~S}$ Am
Cynoglossopsis Brand = Cynoglossum

Cynoglossospermum Kuntze $=$ Lappula

Cynoglossum L. (180-200) subcosmop

Cynoglottis (Guşul.) Vural \& Kit Tan (2) Eur \& Anatolia

Cyphomattia Boiss. $=$ Cynoglossum

Cyphorima Raf. $=$ Lithospermum

Cystostemon Balf.f. ( 15) SW Arab, trop Afr

Dasynotus I.M.Johnst. (1) N Am

Decalepidanthus Riedl (7) Himalayas

Dioclea Spreng. $=$ Arnebia

Diploloma Schrenk $=$ Craniospermum

Echidiocarya A.Gray ex Benth. \& Hook.f. = Plagiobothrys

Echinoglochin Brand $=$ Plagiobothrys

Echinospermum Sw. ex Lehm. = Lappula

Echiochilon Desf. (15) N Afr to SW Asia, Macaronesia, Pakistan \& W Ind

Echiochilopsis Caball. $=$ Echiochilon

Echioides Fabr. = Lycopsis

Echioides Moench $=$ Myosotis

Echioides Ortega = Huynhia

Echiopsis Rchb. $=$ Lobostemon

Echiostachys Levyns (3) S Afr

Echium L. ( 60) N Afr, Eur, Macaronesia, W Asia

Elizaldia Willk. $=$ Nonea

Embadium J.M.Black = Hackelia

Endogonia Lindl. $=$ Trigonotis

*Eremocarya Greene $=$ Cryptantha

Eritrichium Schrad. ex Gaudin $(\sim 50)$ N Am, Asia, Eur

*Exarrhena R.Br. $=$ Myosotis

Exioxylon Raf. = Echiochilon

Friedrichsthalia Fenzl $=$ Trichodesma

Gastrocotyle Bunge (2) N Afr, Arab, S Balkans

Glandora D.C.Thomas, Weigend \& Hilger (8) N Afr \& S Eur

Glochidocaryum W.T.Wang $=$ Microula

Glyptocaryopsis Brand = Plagiobothrys

*Greeneocharis Gürke \& Harms = Cryptantha

Gruvelia A.DC. $=$ Pectocarya

Gymnoleima Decne. $=$ Moltkia

*Gymnomyosotis (A.DC.) O.D.Nikif. = Myosotis

*Gyrocaryum Valdés (1) Spain

Hackelia Opiz ( 45) N \& S Am, Asia, Aus, Eur

Halacsya Dörfl. (1) Balkans

Harpagonella A.Gray (1) N Am

Havilandia Stapf $=$ Trigonotis

Heliocarya Bunge $=$ Caccinia

Hemisphaerocarya Brand $=$ Cryptantha

Henryettana Brand $=$ Antiotrema

Heterocaryum A.DC. ( 6) W Asia

Hippoglossum Hartm. = Mertensia

Hormuzakia Guşul. (2) SE Med

Huynhia Greuter (2) Turkey \& Caucasus area

Iberodes M.Serrano, R.Carbajal \& S.Ortiz $(\sim 7)$ W Med

Isoplesion Raf. $=$ Echium

Isorium Raf. $=$ Lobostemon

Ivanjohnstonia Kazmi $=$ Cynoglossum

*Johnstonella Brand $=$ Cryptantha

Krynitzkia Fisch. \& Mey. = Cryptantha

Ktenospermum Lehm. $=$ Pectocarya

Kuschakewiczia Regel \& M.Smirn. = Cynoglossum
Lacaitaea Brand = Trichodesma

Lappula Moench (50-60) N Am, N Afr, Asia, Aus, Eur

Larephes Raf. $=$ Echium

Lasiarrhenum I.M.Johnst. $=$ Lithospermum

Lasiocaryum I.M.Johnst., (3) C Asia

Leiocarya Hochst. $=$ Trichodesma

Lepechiniella Popov ( 6) NE Afr to SW Asia

Leptanthe Klotzsch $=$ Arnebia

Leurocline S.Moore $=$ Echiochilon

*Lindelofia Lehm. = Cynoglossum

Lithodora Griseb. (3-5) N Afr, W \& SE Eur, SW Asia

Lithospermum L. ( 80) Afr, N \& S Am, Eur

Lobostemon Lehm. ( 30) S Afr

Lycopsis L. (2) W Asia \& Eur

Maccoya F.Muell. $=$ Plagiobothrys

Macromeria D.Don $=$ Lithospermum

Macrotomia DC. $=$ Arnebia

Maharanga DC. (9) C \& E Asia

Mairetis I.M.Johnst. (1) NW Afr

Mapuchea M.Serrano, R.Carbajal \& S.Ortiz = Selkirkia

Margarospermum $($ Rchb. $)$ Opiz $=$ Aegonychon

Massartina Maire $=$ Nonea

Mattia Schult. $=$ Cynoglossum

*Mattiastrum (Boiss.) Brand = Cynoglossum

Megacaryon Boiss. $=$ Echium

Megastoma (Benth. \& Hook.f.) Coss. \& Durieu

ex Bonnet \& Barratte $=$ Ogastemma

Melanortocarya Selvi, Bigazzi, Hilger \& Papini (1) SE Med

Memoremea A.Otero, Jim.-Mejías, Valcárcel \& P.Vargas (1) Eur

Meneghinia Endl. = Arnebia

Meratia A.DC. $=$ Moritzia

Mertensia Roth ( 40) N Am, E Asia, NW Eur

Metaeritrichium W.T.Wang $=$ Microula

Microcaryum I.M.Johnst. (1) C Asia

Microparacaryum (Popov ex Riedl) Hilger \&

Podlech (3) SW Asia

Microula Benth. (30) C Asia

*Mimophytum Greenm. = Omphalodes

Moltkia Lehm. (6) S Eur \& SW Asia

Moltkiopsis I.M.Johnst. (1) NE Afr \& SW Asia

Moritzia DC. ex Meisn. (3) S Am

Munbya Boiss. $=$ Arnebia

Myosotidium Hook. (1) Chatham Islands

Myosotis L. (80-100) subcosmop

Neatostema I.M.Johnst. (1) Med \& Macaronesia

Nephrocarya P.Candargy $=$ Nonea

Nesocaryum I.M.Johnst. (1) San Ambrosio

Nihon A.Otero, Jim.-Mejías, Valcárcel \& P.Vargas

(5) Japan

Nomosa I.M.Johnst. $=$ Lithospermum

Nonea Medik. ( 35) N Afr, W Asia, Eur

Nordmannia Ledeb. ex Nordm. $=$ Trachystemon

Octosomatium Gagnep. $=$ Trichodesma

Ogastemma Brummitt (1) N Afr to Arab

Omphalium Wallr. $=$ Omphalodes

Omphalodes Mill. (20-25) N Am, Asia, Eur

Omphalolappula Brand = Lappula

*Omphalotrigonotis W.T.Wang (1) E Asia

Oncaglossum Sutorý (1) Mexico 
Appendix 2. Continued.

Onochilis Mart. $=$ Alkanna

Onosma L. ( 150) NW Afr, Eur, Asia

Onosmodium Michx. $=$ Lithospermum

Oplexion Raf. $=$ Lobostemon

*Oreocarya Greene $=$ Cryptantha

Oreocharis Lindl. $=$ Mertensia

Oreogenia I.M.Johnst. $=$ Lasiocaryum

Oskampia Baill. $=$ Lycopsis

Osmodium Raf. $=$ Lithospermum

Paracaryopsis $($ Riedl) R.R.Mill = Adelocaryum

*Paracaryum Boiss. $=$ Cynoglossum

Paracynoglossum Popov $=$ Cynoglossum

Paramoltkia Greuter (1) Balkans

Paraskevia W.Sauer \& G.Sauer $=$ Pulmonaria

Pardoglossum Barbier \& Mathez $=$ Cynoglossum

Pectocarya DC. ex Meisn. (15) N \& S Am

Pedinogyne Brand $=$ Trigonotis

Pentaglottis Tausch (1) SW Eur

Pentalophus A.DC. $=$ Lithospermum

Penthysa Raf. $=$ Lobostemon

Perittostema I.M.Johnst. $=$ Lithospermum

Phyllocara Guşul. (1) Irano-Turanian

Picotia Roem. \& Schult. $=$ Omphalodes

Piptocalyx Torr. $=$ Cryptantha

Plagiobothrys Fisch. \& C.A.Mey. ( 70) N \& S

Am, NE Asia, Aus

Platynema Schrad. $=$ Mertensia

Pneumaria Hill $=$ Mertensia

Podonosma Boiss. (3) NE Afr, E Med \& SW Asia

Pollichia Medik. $=$ Trichodesma

Pontechium Böhle \& Hilger (1) E Eur to W Asia

Procopiania Guşul. $=$ Symphytum

Procopiphytum Pawł. = Symphytum

Pseudomertensia Riedl $=$ Decalepidanthus

Psilolaemus I.M.Johnst. = Lithospermum

Psilostemon DC. $=$ Trachystemon

Pulmonaria L. ( 17) E Asia \& Eur

Purshia Spreng. $=$ Lithospermum

Raclathris Raf. $=$ Rochelia

Rhytispermum Link $=$ Aegonychon

*Rindera Pall. $=$ Cynoglossum

Rochelia Rchb. ( 15) Asia to W Eur

Sauria Bajtenov $=$ Eritrichium

Sava Adans. $=$ Onosma

Scapicephalus Ovcz. \& Czukav. = Decalepidanthus

Schistocaryum Franch. $=$ Microula

Sclerocaryopsis Brand $=$ Lappula

Scorpioides Gilib. $=$ Myosotis

Selkirkia Hemsl. (4) S Am, Juan Fernández

Sericostoma Stocks $=$ Echiochilon

Setulocarya R.R.Mill \& D.G.Long = Lasiocaryum

*Sinojohnstonia $\mathrm{Hu}$ (1) E Asia

*Solenanthus Ledeb. $=$ Cynoglossum

Sonnea Greene $=$ Plagiobothrys

Spiroconus Stev. $=$ Trichodesma

Steenhammera Rchb. $=$ Mertensia

*Stenosolenium Turcz. (1) NE Asia

*Stephanocaryum Popov $=$ Trigonotis

Stomotechium Lehm. $=$ Echium

Streblanthera Steud. $=$ Trichodesma

Strobila G.Don = Arnebia

*Strophiostoma Turcz. $=$ Myosotis

Suchtelenia Karel. ex Meisn. (1) C Asia

Symphytum L. $(\sim 35)$ W Asia \& Eur

Tetaris Lindl. $=$ Arnebia

Tetraedrocarpus O.Schwartz $=$ Echiochilon

Thaumatocaryon Baill. (3) S Am
Thyrocarpus Hance (3) Asia

$*$ Tianschaniella B.Fedtsch. $=$ Eritrichium

Toxostigma A.Rich. $=$ Arnebia

*Trachelanthus Kunze $=$ Cynoglossum

Trachystemon D.Don (1) E Med

Traxara Raf. $=$ Lobostemon

Tretocarya Maxim. $=$ Microula

Trichodesma R.Br. (40-50) S Afr to S \& SE

Asia \& Aus

Trigonocaryum Trautv. $=$ Myosotis

Trigonotis Steven ( 60) E \& SE Asia to SE Russia

Tysonia Bolus $=$ Afrotysonia

Ulugbekia Zakirov = Lithospermum

Umbilicaria Heist. ex Fabr. = Omphalodes

Vaupelia Brand $=$ Cystostemon

Wheelerella G.B.Grant $=$ Cryptantha

Winkleria Rchb. $=$ Mertensia

Zoelleria Warb. = Trigonotis

Zwackhia Sendt. = Halacsya

CODONACEAE Weigend \& Hilger (1/2)

Codon L. (2) SW Afr

COLDENIACEAE J. S.Mill. \& Gottschling (1/1)

Coldenia L. (1) trop Afr, S Asia \& N Aus

Lobophyllum F.Muell. = Coldenia

CORDIACEAE R.Br. ex Dumort. (2/ 350)

Acnadena Raf. $=$ Cordia

Ascania Crantz $=$ Cordia

Auxemma Miers $=$ Cordia

Bourgia Scop. $=$ Cordia

Calyptracordia Britton $=$ Cordia

Carpiphea Raf. $=$ Cordia

Catonia Raf. $=$ Varronia

Cerdana Ruiz \& Pav. $=$ Cordia

Cienkowskya Regel \& Rach = Cordia

Coilanthera Raf. $=$ Cordia

Collococcus P.Browne $=$ Cordia

Cordia L. ( 250) pantrop

Cordiada Vell. $=$ Cordia

Cordiopsis Desv. ex Ham. = Varronia

Diacoria Endl. = Cordia

Ectemis Raf. $=$ Cordia

Firensia Scop. $=$ Cordia

Gerascanthus P.Browne $=$ Cordia

Gynaion A.DC. $=$ Cordia

Hemigymnia Griff. $=$ Cordia

Hymenesthes Miers $=$ Cordia

Lithocardium Kuntze $=$ Cordia

Macielia Vandelli $=$ Cordia

Macria Ten. $=$ Cordia

Montjolya Friesen = Varronia

Myxa (Endl.) Lindl. = Cordia

Novella Raf. = Cordia

Paradigma Miers $=$ Cordia

Patagonula L. $=$ Cordia

Physoclada (DC.) Lindl. $=$ Cordia

Pilicordia (A.DC.) Lindl. = Cordia

Piloisia Raf. $=$ Varronia

Plethostephia Miers $=$ Cordia

Rhabdocalyx (A.DC.) Lindl. = Cordia

Quarena Raf. $=$ Cordia

Saccellium Humb. \& Bonpl. = Cordia

Salimori Adans. $=$ Cordia

Sebestena Boehm. $=$ Cordia

Topiaris Raf. $=$ Varronia

Toquera Raf. $=$ Cordia
Ulmarronia Friesen $=$ Varronia

Varronia P.Browne ( 100) Neotrop

Varroniopsis Friesen $=$ Varronia

EHRETIACEAE Mart. (7/ 160)

Antrophora I.M.Johnst, = Lepidocordia

Bourreria P.Browne (48) Neotrop, E Afr

Carmona Cav. $=$ Ehretia

Cortesia Cav. (1) W Argentina

Crematomia Miers $=$ Bourreria

Desmophyla Raf. $=$ Rochefortia

Diplostylus H.Karst. \& Triana $=$ Rochefortia

Eddya Torr. \& A.Gray = Tiquilia

Ehretia P.Browne ( $\sim 50)$ pantrop

Galapagoa Hook.f. $=$ Tiquilia

Gaza Terán \& Berland. = Ehretia

Halgania Gaudich. ( 20) Aus

Hilsenbergia Tausch ex Meisn = Bourreria

Lepidocordia Ducke (2) C \& S Am

Lithothamnus Zipp. ex Span. = Ehretia

Lutrostylis G.Don $=$ Rochefortia

Menais Loefl. $=$ Ehretia

Monomesia Raf. $=$ Tiquilia

Morelosia Lex. $=$ Bourreria

Ptilocalyx Torr. \& A.Gray = Tiquilia

Rhabdia Mart. $=$ Ehretia

Rochefortia Sw. (9) Neotrop

Rotula Lour. $=$ Ehretia

Stegnocarpus Torr. \& A.Gray = Tiquilia

Subrisia Raf. $=$ Bourreria

Tetracoccus Griseb. $=$ Bourreria

Tiquilia Pers. (28) N \& S Am

Tiquiliopsis (A.Gray) A.Heller $=$ Tiquilia

Traxilum Raf. $=$ Ehretia

Zombiana Baill. $=$ Ehretia

HELIOTROPIACEAE Schrad. (4/ 450)

Argusia Böhm. $=$ Heliotropium

Beruniella Zakirov \& Nabiev = Heliotropium

Bourjotia Pomel $=$ Heliotropium

Bucanion Steven $=$ Heliotropium

Cochranea Miers $=$ Heliotropium

Ceballosia Kunkel ex Förther = Heliotropium

Dialion Raf. $=$ Heliotropium

Eliopia Raf. $=$ Heliotropium

Euploca Nutt. $(\sim 100)$ subcosmop

Heliophytum (Cham.) A.DC. $=$ Heliotropium

Heliotropium L. ( 325) subcosmop

Hieranthemum (End1.) Spach $=$ Heliotropium

Hilgeria Förther $=$ Euploca

Ixorhea Fenzl (1) NW Argentina

Lithococca Small ex Rydb. = Euploca

Mallotonia (Griseb.) Britton = Heliotropium

Meladendron Molina $=$ Heliotropium

Messerschmidia L. ex Hebenstr. = Heliotropium

Messerschmidia Roem. \& Schult. = Heliotropium

Myriopus Small ( 25$)$ Neotrop

Nogalia Verdc. $=$ Heliotropium

Notonerium Benth. $=$ Euploca

Orthostachys (R.Br.) Spach = Euploca

Oskampia Raf. $=$ ?Myriopus

Oxyosmyles Speg. = Ixorhea

Pentacarya DC. ex Meisn. $=$ Euploca

Peristima Raf. $=$ Heliotropium

Pioctonon Raf. $=$ Euploca

Piptoclaina G.Don = Heliotropium

Pittonia Mill. $=$ Heliotropium

Preslaea Mart. $=$ Euploca 
Appendix 2. Continued.

\begin{tabular}{|c|c|c|}
\hline Sarcanthus Andersson $=$ Euploca & Draperia Torr. (1) Cal & LENNOACEAE Solms $(2 / 4)$ \\
\hline Schleidenia Endl. = Euploca & Ellisia L. (1) w N Am & Ammobroma Torr. ex A.Gray $=$ Pholisma \\
\hline Schobera Scop. $=$ Heliotropium & Emmenanthe Benth. (2) sw N Am & Corallophyllum Kunth = Lennoa \\
\hline Scorpianthes Raf. $=$ Heliotropium & Endiplus Raf. $=$ Phacelia & Lennoa Lex. (1) $\mathrm{N}$ to $\mathrm{S} A \mathrm{~m}$ \\
\hline Scorpiurus Heist ex Fabr. $=$ Heliotropium & *Eucrypta Nutt. (2) sw N Am & Pholisma Nutt. ex Hook. (3) N Am \\
\hline Synzistachium Raf. = Heliotropium & Eutoca R.Br. = Phacelia & \\
\hline Tetrandra (A. DC \& DC.) Miq. = Heliotropium & Hesperochiron S.Watson (2) w N Am & NAMACEAE Molinari (4/71) \\
\hline Tiaridium Lehm. $=$ Heliotropium & Heteryta Raf. $=$ Phacelia & Andropus Brand $=$ Nama \\
\hline Tournefortia L. = Heliotropium & Howellanthus (Constance) Walden \& R.Patt. & Conanthus S.Watson $=$ Nama \\
\hline Valentina Speg. = Heliotropium & (1) Cal & Eriodictyon Benth. (8) sw N Am \\
\hline Valentinella Speg. $=$ Heliotropium & Hydrophyllum L. (11) N Am & Ernstamra Kuntze $=$ Wigandia \\
\hline Verrucaria Medik. = Myriopus & $\begin{array}{l}\text { Macrocalyx C.J.Trew }=\text { Ellisia } \\
\text { Microgenetes A.DC }=\text { Phacelia }\end{array}$ & $\begin{array}{l}\text { Lemmonia A.Gray }=\text { Nama } \\
\text { Marilaunidium Kuntze }=\text { Nama }\end{array}$ \\
\hline HOPLESTIGMATACEAE Gilg (1/2) & Miltitzia DC. ex A.DC. $=$ Phacelia & Nama L. (56) sw N Am \& trop Am, Hawaii \\
\hline Hoplestigma Pierre (2) W Afr & $\begin{array}{l}\text { Nemophila Nutt. (19) w \& se N Am } \\
\text { Nyctelea (L.) Scop. = Ellisia }\end{array}$ & $\begin{array}{l}\text { Turricula J.F.Macbr. (1) sw N Am } \\
\text { Wigandia Kunth (6) trop Am }\end{array}$ \\
\hline HYDROPHYLLACEAE R.Br. (12/ 250) & Phacelia Juss. (210) w \& e N Am, S Am & \\
\hline Aldea Ruiz \& Pav. = Phacelia & Pholistoma Lilja (3) sw N Am & WELLSTEDIACEAE Novák (1/6) \\
\hline Capnorea Raf. = Hesperochiron & Romanzoffia Cham. (5) w N Am & Wellstedia Balf.f. (6) SW \& NE Afr \& Socotra \\
\hline Colpophyllos Ehret ex C.J.Trew = Ellisia & Tricardia Torr. (1) sw N Am & \\
\hline Cosmanthus Nolte ex A.DC. = Phacelia & Viticella Mitch. $=$ Nemophila & \\
\hline Decemium (A.Gray) Brand $=$ Hydrophyllum & Whitlavia Harvey $=$ Phacelia & \\
\hline
\end{tabular}

